Article

\title{
Discussing the Role of Universities in Fostering Regional Entrepreneurial Ecosystems
}

\author{
Dimitrios G. Ierapetritis \\ Department of Economic and Regional Development, School of Economy and Public Administration, \\ Panteion University of Social and Political Sciences, 136, Syggrou Ave., 17671 Athens, Greece; \\ d.ierapetritis@panteion.gr
}

Received: 27 July 2019; Accepted: 2 December 2019; Published: 16 December 2019

\begin{abstract}
Over the past two decades, various policies have been implemented on an international and national level to support regional competitiveness, in which Universities are often called on to play a crucial role. Taking into account their contribution to the combined performance of education, the advanced research and the networking of knowledge, Universities are recognized as knowledge-intensive institutions and environments that foster human capital development, innovation and entrepreneurship. According to the current practice, Universities include in their mission not only a generalized transfer of know-how, but also the promotion of business thinking and entrepreneurial culture, the establishment of institutions, actions as well as the creation of venture capital, thus contributing further to the promotion of regional entrepreneurial ecosystems. By examining the entrepreneurship development in teaching and learning through the various actions of the Innovation and Entrepreneurship Units of the Greek Universities between 2011 and 2015, the present article aims at assessing the contribution of the Greek Universities to the fostering of regional entrepreneurial ecosystems, making a comparative evaluation of them and strengthening the role of the Greek Universities in regional entrepreneurial ecosystems. Firstly, the theoretical approaches of regional entrepreneurial ecosystems as well as the role of Universities in Regional Development are examined and analyzed. Secondly, it is attempted to record the role of the Greek Universities through the collection and processing of innovation information and actions, utilizing, as a case study, the structures of the Innovation and Entrepreneurship Units. Thirdly, taking into account the results of the research, proposals for the national and regional policy are made.
\end{abstract}

Keywords: entrepreneurial ecosystems; Greece; Innovation and Entrepreneurship Units; Tertiary Education and Regional Development; Universities

\section{Introduction}

In the past, some policies were implemented in EU (European Union) regions which aimed at improving regional competitiveness and strengthening economic growth and social stability by means of supporting businesses in general which engage within a region (Fischer and Nijkamp 1988; Sternberg 2012). Today, empirical researches have revealed that business activities in general cannot contribute to regional development; on the contrary, it is rather a small group of entrepreneurs that are important for economic development (Stam 2015). These are entrepreneurs looking for chances to make profit, willing to take risk by trying innovative products and services and aiming to add to them the maximum possible value.

First, J.B. Say, in the beginning of 19th Century, emphasized the role of the entrepreneur as a prime cause of economic development, defining him as an agent who unites all means of production and who finds the value of the product, the re-establishment of the entire capital it employs, the value of the wages, the interest and rent paid, as well as the profits belonging to himself (Ierapetritis and Lagos 2012). 
According to Kirzner, entrepreneurship is "... a constant effort of a businessman to identify and utilize every single opportunity to make profit" (Kirzner 1973, p. 39), whereas according to Ronstadt it is a process of incremental wealth (Ronstadt 1984). Schumpeter (1934) and Ronstadt (1984), agree that an entrepreneur is an innovative person who takes the risk to devote personal will and time to identify and combine resources and skills with the aim to add value to a product or service (Ronstadt 1984). Hisrich and Peters (2002) argue that an entrepreneur devotes time and effort to create something new, which has value due to the financial, psychological, and social risk taken (Hisrich and Peters 2002). The above approach of entrepreneurship has activated an orientation shift in regional policy from the mere pursuit of a numerical increase of businesses (e.g., new businesses and self-employment) to the pursuit of a qualitative improvement of entrepreneurship (Stam 2015). Within this new framework, the informal interaction relationships were particularly emphasized as it has been proven that they promote the diffusion of knowledge (especially of tacit knowledge) and the performance of innovation. This was also the reason why this new approach was developed, i.e., the approach of the regional entrepreneurial ecosystems. This is an approach that starts from the entrepreneur himself and continues with the productive entrepreneurship ${ }^{1}$. For the ecosystemic approach, entrepreneurship is not just an outflow of the system as entrepreneurs are at the same time important factors for the creation of the ecosystem and the maintenance of healthy conditions in it (Stam 2015). An entrepreneurial ecosystem also includes other entities as important factors, such as big enterprises, universities, financial institutions, and state organizations that support new and growing businesses. Universities are the connecting institution between all partners of an entrepreneurial ecosystem. Universities contribute significantly to economic growth through the combined performance of the advanced research, the knowledge networks, the education and the creation of human capital and entrepreneurship (Audretsch 2014; Carlsson et al. 2002; Cooke et al. 1997; Guerrero and Urbano 2010; and others). At the same time, the role of universities is not limited to a generalized transfer of technology (patents, industrial drawings, spin-off businesses) but includes also the creation of business thinking, actions, institutions and venture capital, thus contributing to the development of entrepreneurship (Audretsch 2014 in Guerrero and Urbano 2016; Cooke et al. 1997).

The EU increasingly emphasizes the "third mission" of Universities next to the two traditional missions of creating knowledge (research) and transferring knowledge (education), which is utilizing research results and connecting them to businesses. The current EU policy cohesion framework that is based on the Strategies for Smart Specialization and the approach of the "quadruple helix" (European University Association 2014, Committee of the Region 2014; Park 2014), aiming mainly at research, technology and innovation, further promotes the role of Universities as main factors of regional development. The updated agenda for Tertiary Education highlights that Universities should pay more attention to the interrelation of the various regional ecosystem stakeholders and the alignment of all their actions with the regional Strategies for Smart Specialization (European Commission 2017; Elena-Pérez et al. 2017). The Entrepreneurial Discovery process is probable the most important "tool" and the moving force of the Strategies for Smart Specialization, as it allows interested parties to interact in order to discover the areas of regional strategic potential. The Entrepreneurial Discovery process is based on the ascertainment that the public sector alone is not able to set the future investment priorities. It is an interactive bottom-up process with the participation of all stakeholders. It is the foundation for the planning of realistic orientations for local development. Universities, as vital regional knowledge institutions, participate actively in the entrepreneurial discovery process. Their ability to implement part of the RIS3 strategy is inextricably linked to the actions of their third mission. This article examines the contribution of Universities to the support of regional entrepreneurial ecosystems through the study of the obstacles and factors accelerating their aforementioned mission. First, the theoretical approaches

1 "The term productive entrepreneurship denotes every business activity that contributes either directly or indirectly to the net outflows of economy or the ability to create additional outflows" (Baumol 1993 in Stam 2015, p. 1765). 
of regional entrepreneurial ecosystems as well as the role of Universities in Regional Development are presented. Second, recording the role of the Greek Universities is attempted through a first collection and processing of innovation information and actions utilizing, as a case study, the structures of Innovation and Entrepreneurship Units of the Greek Universities that were established and operated between 2011 and 2015. Third, taking into account the results of the research, proposals for national and regional policy are made.

\section{Universities and the Regional Entrepreneurial Ecosystems-A Literature Review}

The ecosystemic approach of entrepreneurship can be found in the international literature and policies since approximately fifteen years. The concept of the ecosystem comes from the science of biology and is defined as a set of relationships between living and non-living organisms that have as their functioning goal to maintain their natural states in a balance. The wide use of the term "ecosystem" in social sciences began with Moore's study, who referred to an entrepreneurial ecosystem as the empirical environment of a business (Moore 1993). There is no specific definition that is widely accepted. The definitions are differentiated in relation to the various scales, research fields and data. Most definitions highlight the combination and interaction-mainly through networks-between institutions that produce common cultural values which support business activities. Stam defines the ecosystem as "a sum of independently acting persons and factors that coordinate themselves in such a way to shape the conditions for a productive entrepreneurship" (Stam 2015, p. 1765). According to Malecki there are "dynamic local, institutional, and cultural processes and acting persons that encourage and promote the development of new businesses" (Malecki 2018, p. 1).

Spigel defined in a more integrated way that an entrepreneurial ecosystem is a combination of social, political, economic, and cultural characteristics that support the creation and development of innovative start-ups ${ }^{2}$ and promote new entrepreneurs and other acting persons to take the involved risks by supporting high risk business initiatives. He groups the above characteristics in three categories: material characteristics (universities that educate young entrepreneurs and at the same time produce new knowledge, support policies, infrastructures, open markets, and supporting services); cultural characteristics (supportive culture, outstanding successful businesses); social characteristics (talented human resources, successful local entrepreneurs offering consultation to young entrepreneurs, available investment capital, social networks between entrepreneurs, consultants, and working individuals that allow knowledge diffusion). Spigel notes that the above groups are not isolated from each other; on the contrary, they have been created by and are reproduced from their interactions (Spigel 2017). An entrepreneurial ecosystem is fundamentally a spatial concept. It consists of complex and various acting persons, environmental factors that interact and determine the entrepreneurial performance of an area or a region (Spilling 1996). It includes entrepreneurs, businesses, Universities, regulatory institutions, municipal or regional authorities who-when combined effectively with each other-can be productive and create a dynamic regional economy. Regional entrepreneurial ecosystems resemble other similar concepts of local development, such as business clusters, industrial areas, innovation systems and learning regions, as they focus on the external business environment (cf. Table 1). Still, they are differentiated from the aforementioned concepts, as they focus on the entrepreneur and not on the business: this starts with the private entrepreneur rather than the business but at the same time it emphasizes the essential role of the business environment (Malecki 2018).

2 According to European Start-up Monitor, start-up entrepreneurship is related to new businesses (operating less than ten years) which are characterised by and are related to innovative technologies and an innovative business model and have recorded and aim at a significant increase of employment (Kollmann et al. 2016). 
Table 1. Differences and similarities between entrepreneurial ecosystems and other similar concepts.

\begin{tabular}{|c|c|c|}
\hline Approach & $\begin{array}{c}\text { Industrial District, Cluster, Innovation } \\
\text { System }\end{array}$ & Entrepreneurial Ecosystem \\
\hline Main focus & $\begin{array}{l}\text { Main focus is on economic and social } \\
\text { structures of a place that influence overall } \\
\text { innovation and firm competitiveness. In } \\
\text { many cases, little distinction made } \\
\text { between (fast growing) start-ups and } \\
\text { other types of organizations. }\end{array}$ & $\begin{array}{l}\text { Start-ups explicitly at center of } \\
\text { ecosystem. Seen as distinct from } \\
\text { established large firms and } \\
\text { (lower-growth) SMEs in terms of } \\
\text { conceptual development and } \\
\text { policy formation. }\end{array}$ \\
\hline Role of knowledge & $\begin{array}{l}\text { Focus on knowledge as source of new } \\
\text { technological and market insights. } \\
\text { Knowledge from multiple sources is } \\
\text { recombined to increase firm } \\
\text { competitiveness. Knowledge spillovers } \\
\text { from universities and other large research } \\
\text { intensive organizations are crucial }\end{array}$ & $\begin{array}{l}\text { In addition to market and technical } \\
\text { knowledge, entrepreneurial knowledge } \\
\text { is crucial. Knowledge of the } \\
\text { entrepreneurship process is shared } \\
\text { between entrepreneurs and mentors } \\
\text { through informal social networks, } \\
\text { entrepreneurship organizations, and } \\
\text { training courses offered. }\end{array}$ \\
\hline Locus of action & $\begin{array}{l}\text { Private firms and state is primary locus of } \\
\text { action in building and maintaining } \\
\text { industrial district/cluster/innovation } \\
\text { system. Little room for individual agency } \\
\text { in their creation. }\end{array}$ & $\begin{array}{l}\text { Entrepreneur is the core actor in } \\
\text { building and sustaining the ecosystem. } \\
\text { While state and other sources might } \\
\text { support ecosystem through public } \\
\text { investment, entrepreneurs retain agency } \\
\text { to develop and lead the ecosystem. }\end{array}$ \\
\hline
\end{tabular}

Source: Stam and Spigel (2016).

The modern international literature places entrepreneurs in the "heart" of a successful entrepreneurial ecosystem. They operate in various ways, either as leaders in the development of the ecosystem or as mentors and consultants of new businesses, etc. At the same time emphasis is given next to the entrepreneurs also to the interaction between the acting parts of the ecosystem (high networking density, organization of networking events, cooperation of big companies with local start-ups), to the access to all relevant forms of resources (talent, services, and capital) and the active role of the state. The state maintains its important role as an institution that provides for (e.g., setting the regulatory framework) but not as an institution that leads the ecosystem. Most suitable to identify the opportunities and limitations of the ecosystem and face them are the entrepreneurs themselves, who are related to and contribute along with other "suppliers" (enterprises providing services to other businesses and funding entities) to the preservation of the ecosystem (Malecki 2018).

Each entrepreneurial ecosystem has the following six separate sectors: political, funding, cultural, support, human resources, and markets (Isenberg 2011). In particular, according to the World Economic Forum, the main pillars of an entrepreneurial ecosystem are the human resources, the study curricula at big Universities that promote entrepreneurship and the prevailing business culture (tolerance to risk and failure, presentation of the most successful businesses and innovation in society, etc.), the systems for the support of entrepreneurs-mentors and consultants, the access to national and international markets, the financing means, the state (the legislative and regulatory framework and the infrastructures), and the education and training (provision of skilled human resources) (World Economic Forum 2014).

According to Stam's model, it is the systemic conditions and the conditions of the entrepreneurial ecosystem framework that lead to some specific business activities and to the creation of new value (Figure 1). The above model presents the levels and causality relationships between the levels as well as the internal causality relationships at the various levels. The framework conditions concern the external conditions of the ecosystem, including the social (formal and informal bonds) and natural conditions that allow or prevent human interactions. The systemic conditions concern mainly internal conditions, including networks, talent, knowledge, and supporting services from intermediary entities. The existence of systemic conditions and the relationships between them define the success of the ecosystem (Stam 2015). 


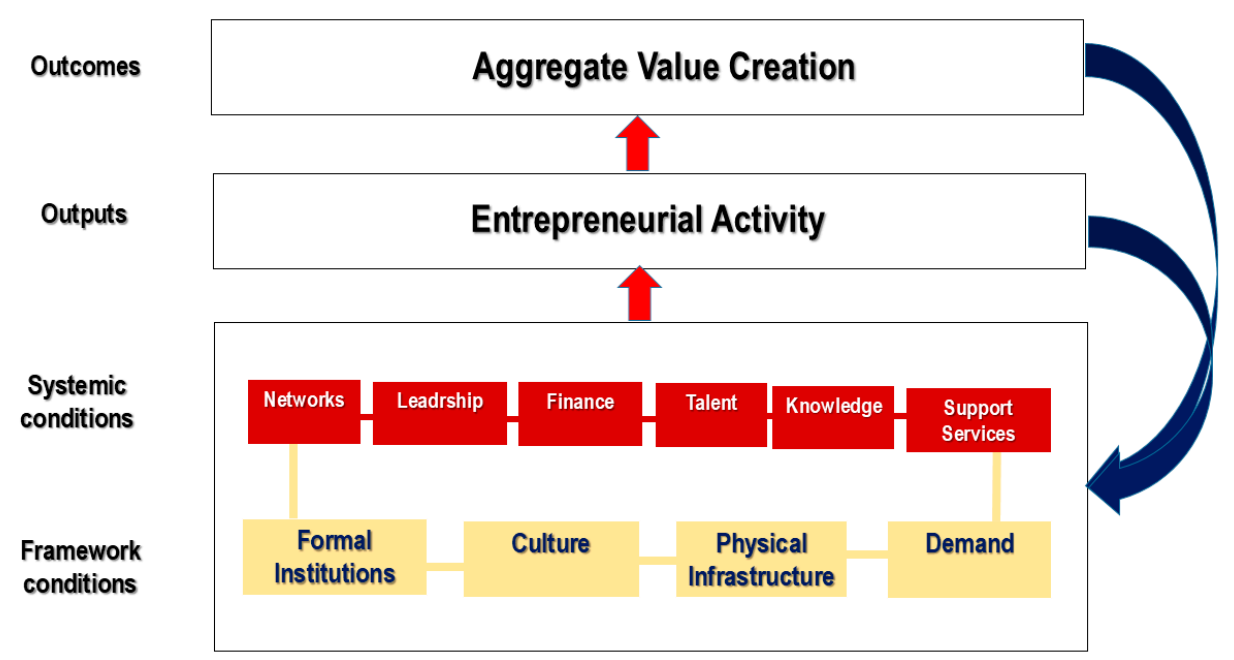

Figure 1. Entrepreneurial ecosystem-Main elements, outflows and results. Source: Stam (2015).

One of the main factors that create a favorable environment for the development of regional ecosystems is the "institutional density" (Amin and Thrift 1994; León et al. 2016, MacLeod 1997). The "institutional density" refers to social and cultural factors, including among others the intense presence and operation of institutions (Universities, Chambers, business networks, organizations for the support of entrepreneurship, local and regional authorities, development companies, research institutes, innovation hubs, etc.), the implementation of an effective regulatory framework for the purchase of goods and labor, the protection of intellectual rights, the existence of a high degree of interaction among regional institutions (e.g., formal and informal contacts on various levels of organization, cooperation, exchange of information, etc.) (Amin and Thrift 1994; León et al. 2016; MacLeod 1997).

In terms of the discussion about the "institutional density" Boucher et al., name universities as important institutional factors for the regional development of knowledge. The members of the academic community are trained and able to create "knowledge innovations", which can formally or informally be transferred to others by means of interactions, networking, education, presentations and publications in scientific journals, etc. (Boucher et al. 2003).

Other studies have also indicated as important factors of a regional ecosystem the existence-among other things-of the following characteristics: a strong business culture that encourages a second attempt after a failure; knowledge bonds among entities both within the Region and outside of it; high-quality skilled outflows (skilled human resources, information, infrastructures, etc.); easy access to the results of research conducted by Universities, a friendly financing and investing system (credits, state subsidies, networks with high risk venture capital funds and "business angels", crowd-funding, microcredits, etc.); powerful networks of social and venture capital; strong national demand; regional and local supporting structures that favor investment and upgrading processes (of both products and procedures), regional policy that promotes competition, cooperation as well as knowledge diffusion and inter-industry merging of businesses.

The special interest in the developments in Tertiary Education that is shown today at the level of regional science is attributed to the research topic focusing on the relationships among universities, knowledge and regional development, which dates back several decades ago. Some main concepts that were used from time to time to enlighten different components and dynamics include the "Triple Helix" for the study of the relationships among Universities-Government and Industry (Etzkowitz and Leydesdorff 2000), the "Learning Region" (Shaw and Allison 1999; Maskell and Tornqvist 2003; Saxenian 1994), the "Quadruple Helix" (Committee of the Region 2014; Park 2014), the "Regional Innovation Systems" (Benneworth et al. 2017) and the "Entrepreneurial University" (Audretsch 2014; Guerrero et al. 2016, 2017). 
The "Entrepreneurial Universities" are closely related to the concept of entrepreneurial ecosystems, together with innovation clusters and knowledge spillover (Kakouris et al. 2018). According to Inzelt, these universities are involved in partnerships, networks and other relationships with public and private organizations promoting a national innovation system interaction, collaboration and co-operation (Inzelt 2004). For Kirby, the "entrepreneurial university" could be a survivor of competitive environments with a common strategy oriented to being the best in its activities, such as producing quality research; having good finances; selecting good students and teachers; and, at the same time, being more productive and creative in establishing links between education and research (Kirby 2005).

The term entrepreneurial university refers to universities that have developed different mechanisms to produce and disseminate knowledge aiming at contributing to regional development and increasing their income (Guerrero and Urbano 2010). They are not isolated from society; they interact closely with industry and government maintaining their relative independency. The resolution of the tensions between the principles of interaction and independence is the creation of a hybrid organizational format. Moreover, there is a continuing renovation of the internal structure of the "Entrepreneurial Universities" as their relation to industry and government changes; and of industry and government as their relationship to the universities is revised (Etzkowitz 2013).

According to EC, and OECD (2012) the "Entrepreneurial University" is epitomized by innovation throughout its teaching and learning, research, knowledge exchange, governance and external relations. A study of the modern concept of the "Entrepreneurial University" reveals that there is no commonly accepted definition for it. Still, the concept could be described by means of the seven aspects-characteristics that most of the definitions attribute to the "Entrepreneurial University": entrepreneurship development in teaching and learning, pathways for entrepreneurs, leadership and governance, organizational capacity, people and incentives, university-business/external relationships for knowledge exchange, the "Entrepreneurial University" as an internationalized institution and measurement of the impact of the "Entrepreneurial University" (EC, and OECD 2012).

Entrepreneurship development in teaching and learning highlights the need for the organizational structure of the Universities to support entrepreneurial development as well as to deliver entrepreneurial learning, via other methods except traditional lectures. "Entrepreneurial Universities" deliver their teaching in entrepreneurship through a range of methods such as mentoring, living labs, cross disciplinary learning, support of students to run their own start-up businesses, competitions and awards, etc. They provide teaching and extra-curricular actions that encourage the development of entrepreneurial behavior. Collaboration with stakeholders of the external environment is also an important resource for the "Entrepreneurial Universities" because it provides valuable relationships, expertise and entrepreneurial experience that is valuable in entrepreneurship education. Moreover, the "Entrepreneurial Universities" encourage their staff to keep the entrepreneurial curriculum updated integrating the results of current research into teaching.

Typical examples of entrepreneurship development in teaching and learning in European "Entrepreneurial Universities" are the following: EM Lyon Business School (France) which is structured in such a way that it supports entrepreneurial learning, providing "the skills and attitudes to become an entrepreneur" (EM Lyon Business School 2019); the University of Wismar (Germany) which aims at spreading an entrepreneurial spirit via integrating a set of skills into study programs (Hochschule Wismar 2019); the University of Applied Sciences Jena (Germany) which, via the Center for Innovation and Entrepreneurship, supports entrepreneurial behavior from the creation of awareness and stimulation of ideas to development and implementation (Ernst-Abbe-Hochhule Jena 2019); the Aalborg University (Denmark) which operates the Supporting Entrepreneurship program that supports, facilitates, and motivates knowledge-based entrepreneurship and prepares students for a career after their studies as entrepreneurs, through the provision of training, mentoring, coaching and the provision of infrastructural support (Aalborg University 2019); and a group of Finnish Universities such as the University of Tampere (Finland) which integrates innovation projects with Demola, 
(a Finnish open innovation platform that provides support from professors and industry professional to multidisciplinary student teams, (Demola 2019)), etc.

The "Entrepreneurial University" is a suitable place for innovation-individually or collectively-from students and academics, where knowledge and skills are delivered in greater depth than other levels of education. Moreover, in university entrepreneurship education, programs and personal skills are combined with technical business training. Research centers provide complementary and academic support on scientific or technological aspects. Today, entrepreneurship support policies based on technology are developed and implemented both at a national and an international level, whereas Universities-having a dual role and focusing on both entrepreneurship and innovation-participate in an overall strategic promotion of competitiveness, innovation and economic growth. The international literature recognizes the role of Universities as particularly vital for the development of human capital, knowledge and entrepreneurship (Audretsch 2014; Carlsson et al. 2002; Elena-Pérez et al. 2017; Guerrero and Urbano 2016; Isenberg 2010; Mason and Brown 2014; Poblete and Amorós 2013; and others). More specifically, as separate economic entities they contribute to the economic development of the regions in which they are located on four different levels: first as employers, buyers of goods and services from local businesses, but also as attraction poles for students who spend money in the regional economy; second, as institutions for the commercialization of the created knowledge through intellectual rights, structures for know-how transfer, scientific parks and establishment of spin-off businesses; third, as attraction poles that educate and keep students whom they train and offer to the regional businesses as employees; and four, as institutional factors participating formally or informally together with other institutions in regional associations and networks of learning, innovation and governance (Boucher et al. 2003). The literature related to innovation recognizes the role of Universities for the strengthening of innovation performance by means of establishing spin-off businesses and developing and registering patents and licenses as well as their role as knowledge providers for their skilled graduates, scientific publications, and consulting (Guerrero et al. 2016).

Universities are the most recognized acting institutions in entrepreneurial ecosystems as they act as communication and cooperation networks for the ecosystem (Malecki 2018). Due to their geographic proximity and inclusion they usually act as agents of change that promote human interaction, know-how transfer and building of trust between different entities and interests (Harrison and Turok 2017). Consequently, universities are important connecting institutions between all the entities participating in regional entrepreneurial ecosystems (private persons or organizations), whereas at the same time they interact with them and strengthen the regional entrepreneurship and innovation ability (Guerrero et al. 2016). They deliver entrepreneurship education that cultivates and develops the attitudes, the knowledge and the competencies that allow students to operate in an entrepreneurial way in all their actions (Ierapetritis 2016). They provide to a regional ecosystem talented human resources (entrepreneurs, intrapreneurs, and employees), contribute to the establishment of a business culture (principles and attitudes), support the relationships and bonds between entrepreneurs, high risk venture capital funds, business hubs, and develop particular personal skills or knowledge, such as team work, leadership, innovation/creativity, ability to work under pressure, self-directed learning and ethics (Guerrero et al. 2017).

Still, the general factors and obstacles that have been revealed by research from time to time should be mentioned here, as they can inhibit the cooperation of universities with businesses in the region and consequently their participation in the planning and implementation of regional policies, regardless of the nature of the region and the characteristics of the universities. The aforementioned obstacles are related to the following; first, reducing interest in cooperation, which derives from the variety of 
motives leading to scientific research ${ }^{3}$ of both the academic community and the businesses (obstacles related to orientation); second, conflicts that quite often appear between two parties interested in issues concerning the exploitation of intellectual rights arising from the results of a joint research (Bruneel et al. 2010); and third, the difficulty of finding a cooperation field due to their different knowledge areas.

\section{Methodology}

By examining the entrepreneurship development in teaching and learning through the various actions of the Innovation and Entrepreneurship Units of the Greek Universities between 2011 and 2015, this article aims at discussing the contribution of the Greek Universities to the fostering of regional entrepreneurial ecosystems, and strengthening the role of the Greek Universities in regional entrepreneurial ecosystems.

Modern international studies have revealed a remarkable heterogeneity but also a difference of range in the participation of Universities in the shaping of knowledge networks and the development in the regions in which they are located. The above participation depends both on the implemented national policy and on other factors, such as the type and nature of each Region, the number, size and scientific orientation of the Universities operating in the Region, etc. The main factors that determine the degree of inclusion of Higher Education Institutes in regional ecosystems, the promotion of a learning environment, the development of skills and resources for competitiveness and social convergence are the following.

- The extent of regionalization within the national system of tertiary education (to what extent the funding resources are distributed nationally or transferred for distribution at a regional level)

- The type of region with regard to the characteristics of center and periphery

- The nature of the regional identity

- The existence and type of regional networks

- The number and scale of Universities in the region

The international literature reveals four main types of University participation in regional development:

- $\quad$ Single-player Universities in peripheral regions

- Traditional Universities in core Regions

- Multiplayer Universities in peripheral Regions

- Newer technologically oriented Universities in core regions (Boucher et al. 2003).

More specifically, the first type of university participation in regional development concerns big institutions that operate individually in smaller and peripheral regions. These universities are they only source of knowledge, mainly due to the lack of other tertiary education institutes, state research institutes and big companies that have research and development departments. They are often a necessary partner for the success of any policy or project. They participate more actively in the shaping of the institutional environment than a mere participation in a development initiative. The relationships and networks that develop in decentralized regions usually acquire a formal, typical character due to the spatial extent of the everyday cooperation and the distance between the partners. The second type concerns the traditional universities that are located in core metropolitan regions, have a long history and an international prestige, whereas strategically they focus more on targets of national and international scale. Still, these universities maintain at the same time a role for the development

3 The overall low interest of the members of the academic community to cooperate is often attributed to the lack of institutionalised motives for an academic career, as this is exclusively related to traditional bibliometric indicators. 
of the Region, in which they are located, which may not be that obvious but it is almost exactly as important. Besides from the official activities of the Schools and Faculties of the above Institutes, some individual members of the academic community participate personally—often informally—in regional development processes, organizations, and/or means.

The universities that are located in peripheral but administratively core regions, in which they coexist with other Universities, with which, however, they have different locations, specializations, and modules, often form a third type of informal University participation in regional development. They do not always maintain a clear position but can be involved either by providing knowledge or by shaping a regional strategy. The administrations of the above Universities are not much interested in participating in regional and local networks and usually use their powers to face internal issues, such as the modernization of the Faculties, etc. On the other hand, the academic staff of the above Universities is not interested in participating in the administration of the Institutes. There is often an intense competition among Universities of this category, while quite often local rivalries are reflected in the academic area. Each single one of the Universities tries to promote its own actions as opposed to the ones of the other Universities. The newer technologically oriented Universities in core regions with a technological nature and a vocational orientation that are located in the core region or close to the core region constitute the fourth type of University participation in regional development. Quite often their main facilities are located in less privileged neighborhoods and areas. The character of the area where the University is located is utilized for the strategic promotion of the University's interests to participate in actions of regional and local scale. Some Universities of this category emphasize more the role they play as cultural centers for the local communities and the broader subunits of the region in which they are located (Boucher et al. 2003).

With respect to the methodological steps, all Greek Universities are listed divided in groups according to their actions categories based of the classification by Autio and Rannikko (2016). The classification of Autio and Rannikko (2016) groups the support actions of entrepreneurship in buffering, bridging and entrepreneurs' capacity boosting actions. The buffering actions include actions for the provision of measures to secure businesses from the lack of resources and from dependence as well as for the provision of benefits, such as training, consulting, low cost working spaces (incubators), etc. The bridging actions aim selectively at high performing cooperation projects by means of networking processes and by connecting businesses with "business angels", high risk venture capital funds, etc. The entrepreneurs' capacity-boosting actions concern the cultivation of abilities in innovation and performance.

Following the grouping of the Universities according to Boucher et al. (2003), some additional data is evaluated which relates to the number of students participating in the actions of the Innovation and Entrepreneurship Units during the studied period, i.e., between 2011 and 2015. Then it is attempted first to discuss and evaluate the role of Universities, based on the entrepreneurial development in teaching and learning and second to investigate the following research hypothesis: Single-player universities that are located in peripheral regions has a stronger contribution to the shaping of the institutional entrepreneurial environment in regional scale, than other groups such as traditional universities that are located in core metropolitan regions, multiplayer universities in peripheral regions, and the newer technologically oriented universities in core regions on participating in regional development.

\section{Discussion}

\subsection{General}

It has been ascertained at an international level that universities have not succeeded in transferring their knowledge and know-how adequately to the business community and just few business, usually big, well-established corporations, maintain a closer contact to universities and they are the only ones that finally benefit from the advantages of this relationship (Poblete and Amorós 2013). Modern studies at a national level have revealed that scientific networks are very rare, there are only a few cooperation 
projects between public research and industry, whereas the national performance in innovation and entrepreneurship is very low (European Commission 2019; DiaNEOsis 2016). By looking first into the total national R\&D expenses, it was ascertained that although they recorded a slight increase over the period 2011-2017 they are still very low. More specifically, in 2017 they amounted to 1.14\% of the GDP (2033 million euros), i.e., much less than the mean of the EU member states (2.07\% of the GDP and 318,108 million euros). According to recent available data from Eurostat (2019), the participation of tertiary education in the overall expenses for R\&D decreased significantly in Greece over the period 2007-2017 as opposed to the R\&D expenses in the total of the EU member states, where the percentage of the expenses in Tertiary Education remains almost unchanged. In particular, over the period 2007-2017 a decrease of the participation of Universities in R\&D was observed, which amounted to 42.9\% (2007: 49\%, 2017: 28\%) as opposed to the total mean share of the R\&D expenses of the Higher Education Institutes of the EU member states, which remained practically unchanged (2007: 23\%, 2017: 22\%) (Eurostat 2019).

Similar results arise also from the evolvement of the R\&D expenses of the Institutes (in million euros) over the period 2011-2017. At the same time, Greece underperforms also with regard to the number of co-publications of public and private sector compared to the mean performance of the EU member states. According to Eurostat (2019), although the number of co-publications of the public and private sectors is very small per million inhabitants, it is also decreasing throughout the country as indicated over the recent period 2011-2018 that recorded an overall decrease of 32.4\% (2011: 35.11 and 2018: 23.73 co-publications per million inhabitants; cf. Figure 2).

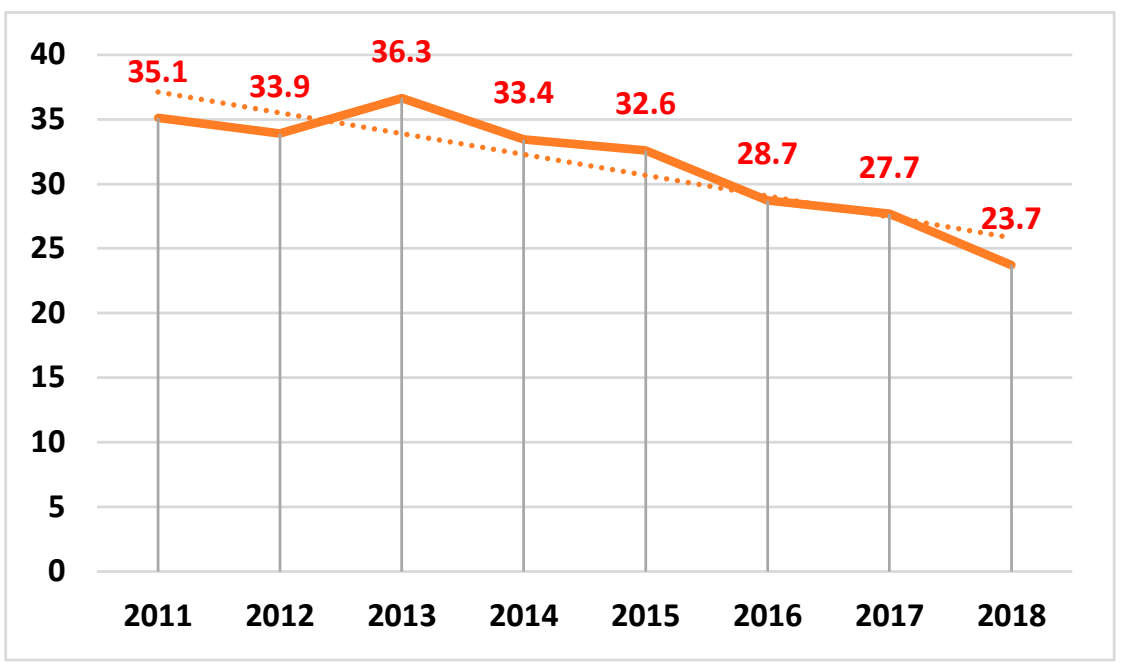

Figure 2. Number of research co-publications of public and private sector per million of inhabitants ${ }^{4}$ in Greece between 2011 and 2018. Source: European Innovation Scoreboard (2019). Greek profile over time. https://interactivetool.eu/EIS/EIS_2.html\#f.

Figure 3 presents the percentage of the Greek innovative SME that cooperated with other businesses or organizations during the period 2011-2018. The number of innovative SME, as a percentage of the total number of SME, that cooperated with other enterprises or organizations (public or private) is in fact the indicator that measures the flow of knowledge between public research institutes and private enterprises.

4 This indicator records the public-private research interconnections and active cooperation activities between researchers from private businesses and researchers from the public sector that lead to academic publications. The definition of "private sector" excludes the private medical and healthcare sector. 


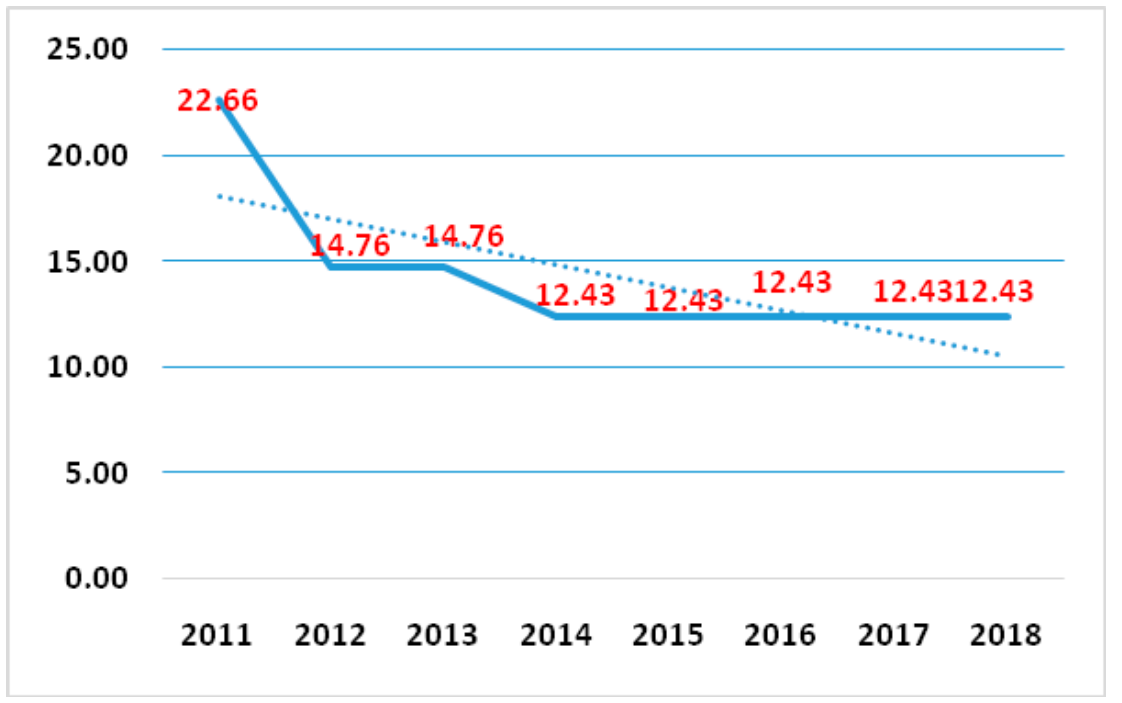

Figure 3. Number of innovative SME that cooperate with other organizations in Greece 2011-2018. Source: European Innovation Scoreboard (2019), Greek profile over time. https://interactivetool.eu/EIS/ EIS_2.html\#f.

During the examined period 2011-2018, the innovative SME that cooperate with other organizations recorded a decrease of $45.1 \%$ (2011: $22.66 \%$ and 2018: $12.43 \%$ ). Table A1 illustrates the total R\&D expenses that took place in institutions of Tertiary and Post-Secondary Education over the period 2001-2016 at the level of Region (spatial unit NUTS2) and throughout the entire country. The information of Table A2 reveals that although the expenses have an uptrend (increase of R\&D expenses for the entire country by $46.2 \%$, i.e., in 2001: 382.5 million euros, and in 2016: 559.35, million euros), the R\&D expenses that took place in the Greek Tertiary and Post-Secondary Education Institutes are quite limited. The highest share is recorded in the Universities located in the Region of Attica (2016: 228.57 million euros) that account for $40.9 \%$ of the total R\&D expenses of the Tertiary and Post-Secondary Education. They are followed by the Institutes that are located in Central Macedonia (2016: 77.6 million euros), Western Greece (2016: 60.5 million euros), and Crete (2016: 60.1 million euros).

Table A3 illustrates the information on the staff of the Tertiary and Post-Secondary Education at the level of region (spatial unit NUTS2) that is employed in R\&D per region. The table's information reveals that, over the period 2001-2015, there was an increase of the number of persons employed in R\&D conducted by the Tertiary and Post-Tertiary Education Institutes, amounting to $65.5 \%$ (2001: 33,507; 2015: 55,467). During the last year, 2015, it was revealed that $43.1 \%$ of them were employed by Educational Institutes located in the Region of Attica. They are followed by the Tertiary and Post-Tertiary Education Institutes that are located in the Regions of Central Macedonia (17\%) and Western Greece (8.8\%).

\subsection{Innovation and Entrepreneurship Unit}

As already explained, the role of Universities is not limited to the generalized transfer of technology (patents, industrial drawings, spin-off enterprises). It includes also the creation and establishment of entrepreneurial thinking, actions, institutions and venture capital, thus contributing to the development of local entrepreneurship. Having examined the contribution of Universities to the promotion of regional entrepreneurial ecosystems, the development of venture capital and entrepreneurial thinking, the results of the innovative action of Innovation and Entrepreneurship Units are presented, which operated in the Greek Universities between 2011 and 2015. During the period 2011-2015, the Innovation and Entrepreneurship Units were an individual Unit of the horizontal Employment and Career Structure in almost all Universities. They were part of the Thematic Priority, "Design, introduction and implementation of reforms in education and training systems with the 
target to develop employment, improve the relation between initial and vocational training aiming at a knowledge-based economy", of the Operational Programme "Education and Lifelong Learning 2007-2013".

Over the period 2011-2015, they operated in a total of thirty-seven (37) Tertiary Education Institutes, out of which twenty-two (22) were Universities (whereas the rest fifteen (15) were Technological Education Institutes (TEI) $)^{5}$. The objective of the Innovation and Entrepreneurship Units was to support students to acquire new knowledge, develop skills related to entrepreneurship as well as develop a friendly attitude towards entrepreneurship. According to the information of Table A4, the real budget for the expenses related to the operations of the Innovation and Entrepreneurship Units amounted in Universities to approximately 6 million euros (EUR5,928,042). In total, throughout the entire operation period of the Innovation and Entrepreneurship Units the beneficiaries amounted to 53,611 students. The Innovation and Entrepreneurship Units are a characteristic and innovative initiative of the Tertiary Education Institutes. It should be noted that during a research conducted by the General Secretariat for Industry among start-ups already existing and in the process of being set up, $7 \%$ of them declared-almost immediately after the completion of the action Innovation and Entrepreneurship Units-having participated in the actions of the Innovation and Entrepreneurship Units of the Universities (General Secretariat for Industry 2016).

An examination of the information of Table A4 reveals that the great majority of the beneficiaries (11,459 students: $21.4 \%$ ) were students of the Hellenic Open University (a fact that is obviously related to the special status of remote teaching of the Hellenic Open University). They were followed by the beneficiaries of the Athens University of Economics (6113 students: 11.4\%), the National Technical University of Athens (5476 students: 10.2\%) and the University of the Aegean (5010 students: 9.3\%). The lowest position is held by the Panteion University, the Innovation and Entrepreneurship Unit of which 196 had benefiting students enrolled ( $0.3 \%$ of the total of the benefiting students).

Consequently, in an attempt to evaluate the various actions of the Universities' Innovation and Entrepreneurship Units that were implemented over the period 2011-2015 according to the classification of support measures supported by Autio and Rannikko (2016) the above actions were grouped in the Tables A5-A7. The classification of Autio and Rannikko (2016) groups the support actions of entrepreneurship in buffering, bridging, and entrepreneurs' capacity-boosting actions. The buffering actions include actions for the provision of measures to secure businesses from the lack of resources and from dependence as well as for the provision of benefits, such as training, consulting, low-cost working spaces, etc. The bridging actions aim selectively at high performing cooperation projects by means of networking processes and by connecting businesses with "business angels", high risk venture capital funds, etc. The entrepreneurs' capacity-boosting actions concern the cultivation of abilities in innovation and performance.

The information of Tables A5-A7 reveals with regard to the buffering actions of students that the Universities focused primarily on teaching subjects related to entrepreneurship and innovation and paid little attention to the creation of relevant teaching material to support the lessons, and even less attention to the making of business plans for virtual businesses and researches/studies, whereas only one University operated an experimental start-up hub. The bridging actions that took place within the framework of the Innovation and Entrepreneurship Units concerned mainly the creation of websites, the organization of open seminars, the organization of visits to businesses and the implementation of actions for publicity, promotion and diffusion of the results of the Innovation and Entrepreneurship Units' operation. Finally, as regards the actions for the strengthening of the students' entrepreneurial ability, various programs for the consultation and guidance of students in issues related to entrepreneurship and innovation took place and various case studies were conducted. A smaller

5 Next to the operation of Innovation and Entrepreneurship Units at the Universities similar Units operated at the Technological Educational Institutes (TEI) having a total budget amounting to 3.2 million EUR and 23,802 participating students. 
number of Universities operated innovation workshops and "nurseries of ideas". More specifically, investigating the implementation of the individual capacity "boosting" actions of the Innovation and Entrepreneurship Units in the period 2011-2015, most of the Universities offered guidance and counseling on entrepreneurship and innovation (82.6\%). A significant percentage produced Case Studies for the needs of the courses. However, there was a limited number of Universities that organized entrepreneurial ideas workshops (see "Nursery of Ideas", just $4.3 \%$ of them), Documentation Centres (4.3\%), and subscriptions to international relevant scientific journals (4.3\%). The Athens University of Economics, the University of Ioannina, the University of Macedonia, the University of Patras and the University of Piraeus stand out (4 capacity "boosting" actions).

Most of the bridging actions offered by the Greek Universities were the creation of website $(82.6 \%)$, the organization of open seminars (73.9\% of Universities), visits to innovative enterprises $(60.9 \%$ of universities) and dissemination actions (56.5\%). Particularly, limited were the actions of contacts with producers $(4.3 \%)$, the organization of summer schools $(4.3 \%)$, the creation of exhibition areas $(4.3 \%)$, and the invitation of speakers (4.3\%). The National Technical University of Athens and the University of the Aegean are emerging as the Universities that offered the largest number of bridging actions. They are followed by the Democritus University of Thrace, the Hellenic Open University, the Economic University, the University of Macedonia and the University of Patras with four (4) bridging actions throughout the period 2011-2015.

Finally, in the buffering actions developed by the Universities, the courses for entrepreneurship and innovation (100\% of universities) and the production of training materials $(82.6 \%)$ stand out. Particularly, limited was the number of actions such as incubators operation (4.3\%), the preparation of a Business Plan Preparation Guide (4.3\%), and the business gaming (4.3\%). The Athens University of Economics and Business (seven actions) and the National Technical University of Athens (six actions) implemented most of the buffering actions during the period 2011-2015.

An attempted meta-analysis of the information included in the evaluation report of the Innovation and Entrepreneurship Units for the period 2011-2015, during which a field survey was conducted, resulted in some very useful conclusions about the result and the significance of such initiatives in Tertiary Education Institutes (cf. Table A11). In general, according to the results of the research that was conducted on behalf of the Managing Authority of the Operational Programme "Human Resources Development, Education and Lifelong Learning" the following conclusions were drawn:

Overall, the students stated being very satisfied with their participation in the actions of the Innovation and Entrepreneurship Unit. The field survey indicated their satisfaction with the organization of open seminars and with the classes related to entrepreneurship and innovation, but also with the provision of consultation and guidance actions. Of course, there is always room for improvement, especially with regard to acquiring skills and experience (e.g., making innovative business plans and visiting businesses incorporating innovations in their operation). More specifically, the field survey indicated the following.

- The students stated that they were satisfied with the design of the seminars related to entrepreneurship and innovation $(76.9 \%$ of the students evaluated them from very good to excellent).

- The students stated that they were also satisfied with the design of the subjects-lectures related to entrepreneurship and innovation as well as with the selection of the teaching staff for the above subjects ( $75.4 \%$ and $73.8 \%$ evaluated them from very good to excellent respectively).

- They were particularly satisfied with the teaching material related to innovation issues that was created and utilized within the framework of the operation of the Innovation and Entrepreneurship Units ( $74.6 \%$ evaluated it from very good to excellent).

- They found the actions related to consultation and guidance as well as the support for issues concerning innovation very useful (66.2\% evaluated them from very good to excellent). 
- It was ascertained that there is room for improvement in issues related to acquiring knowledge and skills related to making innovative business plans $(28.5 \%$ evaluated these actions from not at all satisfactory to merely satisfactory).

- Some weaknesses were also revealed in the actions related to visiting production entities that incorporate innovations in their operation $(28.5 \%$ evaluated these actions from not at all satisfactory to merely satisfactory).

At the same time, the above survey revealed also a series of weaknesses and/or problems that need to be tackled in order to further strengthen the role of the Innovation and Entrepreneurship Units-and consequently also the role of Universities-in fostering regional entrepreneurial ecosystems. More specifically, the survey revealed the following.

- The information on the operation and actions of the Structure was inadequate or was not provided sufficiently early, a fact that resulted in limited interest and low student participation.

- Lack of an institute strategy for the identification of ways for self-financing that would allow the sustainability of the Units, regardless of the provision of funding from the Structural Funds.

- Problems related with the geographic distribution of the operating University Faculties, which became obvious during the operation of the Units. The above concerns mainly Universities that are located on islands (University of the Aegean, Ionian University) as well as Universities operating in more than one Regional Units (e.g., Democritus University of Thrace, University of Thessaly, University of the Aegean, and University of Western Macedonia).

- Restricted number of actions.

- Inability of student teams from different Universities to cooperate with one another (Trek Consulting 2016).

The current structure and the basic academic characteristics of the Greek Universities such as the year and the region of establishment (NUTS2, NUTS3, and LAU1), Schools and Departments are presented in Table A9. Table A10 illustrates the cumulative results of entrepreneurial development in teaching and learning of the Greek Universities through the operation of Innovation and Entrepreneurship Units between 2011 and 2015 thus facilitating the benchmarking process. In particular, the Greek Higher Education Institutes are grouped according the criteria of Boucher et al. (2003) as these operate based on data presented in Table A9. The University of the Aegean, the University of Western Macedonia, the University of Thessaly the Democritus University of Thrace, the Ionian University, the University of Central Greece and the University of the Peloponnese are grouped as Single-Player Universities in Peripheral Regions. The National and Kapodistrian University of Athens, the University of Piraeus, the Aristotle University of Thessaloniki, the Agricultural University of Athens, the University of Macedonia, the Athens University of Economics, the National Technical University of Athens and the Athens School of Fine Arts are grouped as Traditional Universities in Core Regions. The University of Crete, the Technical University of Crete, the University of Patras, and the University of Ioannina are grouped as Multiplayer Universities in Peripheral Regions. With respect to the group Newer Technologically Oriented Universities in Core Regions no Greek University was identified having these characteristics.

The presentation following the grouping of the Universities includes the following. First, information on the participation of students (number of participating students) for the entire duration of the funded operation of the actions of the Innovation and Entrepreneurship Units as a percentage of the total number of students; second, presentation of all the actions carried out by the Innovation and Entrepreneurship Units of each Greek University, but also the groups of individual actions, i.e., buffering actions, capacity boosting actions, and bridging actions.

The information of Table A10 confirms the basic Hypothesis that Single-Player Universities that are in peripheral regions have a stronger contribution to the shaping of the institutional entrepreneurial environment on a regional scale. The Greek Single-Player Universities in Peripheral Regions have 
managed to attract higher percentages of participating students in actions of their Innovation and Entrepreneurship Units; 34\% of those studying at the Greek Universities of peripheral regions participated in the actions of the Innovation and Entrepreneurship Units, i.e., three times more than the average of the University students countrywide (11\%, cf. Table A8). An examination of the decentralized Universities revealed that the University of the Aegean (40\% participation), the University of Western Macedonia (41\%), the University of Thessaly (30\%), and the former University of Central Greece (66\%) recorded the highest percentages of participation. Still, the number of actions implemented was not as high as in the other two groups of Universities, while they also lagged behind in capacity-boosting actions.

Almost all traditional Universities that are located in core regions (Athens and Thessaloniki) recorded significantly lesser participations. More specifically, 15\% of the students attending the University between 2011 and 2015 were also participants in the actions of the Innovation and Entrepreneurship Units. Particularly low participation was recorded at the Panteion University (1\%), the Aristotle University of Thessaloniki (2\%) and the National and Kapodistrian University of Athens (3\%). An important differentiation was recorded in the Athens University of Economics and the National and Technical University of Athens, as the participation recorded amounted to $33 \%$ and $47 \%$ respectively. This differentiation is mainly attributed to the various knowledge fields in which the aforementioned Universities (cf. Table A9) specialize in as well as to their innovative approaches regarding entrepreneurial training issues. The two aforementioned Universities excel also in terms of the total number of actions (15 and 13 actions, respectively) followed by the University of Piraeus (11 actions) and the University of Macedonia (10 actions).

Finally, on a comparative level only a small percentage of the students of the Universities of the third group, i.e., the Multiplayer Universities in Peripheral Regions, participated in the Units (12\% on average, i.e., slightly higher than the country's overall percentage). Out of this group, the University of Crete stands out with a participation percentage amounting to $23 \%$. The Universities of Patras and Ioannina stand out due to the total number of their actions (11 actions).

This study attempted a first assessment of the contribution of the Greek Universities to the fostering of regional entrepreneurial ecosystems by examining one aspect of said contribution, namely the field of entrepreneurial development in teaching and learning. There is an important margin for further research and evaluation of the above contribution by means of other aspects and operations, such as the assessment of the research performance, the cooperation and other kinds of networking on a local and regional level as well as the study of the factors that promote or hinder them.

\section{Conclusions and Policy Recommendations}

The contribution of Universities to the strengthening of regional entrepreneurial ecosystems is essential. They participate actively both in the development of appropriate human resources through entrepreneurial education and training and to the shaping of a pool of talented individuals (administrative and technical talents) in all sectors and branches of specialization. Concurrently, they play a vital role in promoting a culture favoring entrepreneurship (creativity, tolerance to risk and failure, promotion of successful business models) and shaping entrepreneurial ideas for new businesses. Their role is also important as they offer a support system through the operation of business hubs and accelerators through their cooperation with mentors and consultants. Additionally, they make an important contribution to the creation of a dense institutional networking in the regional and local entrepreneurial ecosystem and by means of this networking also to the organization of interconnection events between the local enterprises and the rest of the members of the regional entrepreneurial ecosystem. In Greece during the period 2011-2015, the contribution of the Innovation and entrepreneurship units that operated in the Greek universities was very important through buffering actions (66 actions), bridging actions (75 actions), and capacity boosting actions (56 actions) of students and potential future entrepreneurs (Autio and Rannikko 2016). 
Taking into account the new geographic distribution of the Greek Universities, as this was shaped following the recent merging of some Technological Institutes and Universities (cf. Table A9, Figure A1), the Universities have a very important role to play for the strengthening of entrepreneurial ecosystems at regional and local level. To develop a relationship between Universities and regional entrepreneurial ecosystems, this relationship needs to be "win-win". Universities can benefit not only from the funds they can receive from the Structural Funds but also from a strategy for education that takes into account the country's needs and developments, the researches with commercial interest, the connection between businesses and local authorities as well as the actions that improve the international prestige of the Universities, increase the number of their students and offer alternative sources of income.

It is stressed that special attention must be paid to entrepreneurial development in teaching and learning, which in the meantime is considered a crucial means of support for a successful entrepreneurial behavior (Walter and Block 2016) and a main aspect of the modern Entrepreneurial University. Towards this direction the contribution of Universities by taking initiatives similar with that of the Innovation and Entrepreneurship Units that operated between 2011 and 2015 is considered especially important. The strengthening of the operation of Innovation and Entrepreneurship Units at the Universities by means of similar actions and more emphasis on establishing an entrepreneurial culture, providing particular entrepreneurial knowledge, skills and experiences through the participation of entities from the local entrepreneurship (business planning, visits to innovative enterprises and learning from them, etc.) that will be provided along with a relevant certificate of attendance for the students, will further promote the contribution of Universities.

Universities need to work towards the direction of understanding the regional ecosystems in which they participate. Both the administrations and the members of the Universities wish to be a vital source of knowledge and neglect the dynamic role that they could play for the development of a healthy and resistant community. Still, to have influence as business and innovation institutions, they need to become part of the student community, the business community and others and to overcome any bureaucratic restrictions (Feld 2012). What is actually missing from the members of the University community, besides from the interest in entrepreneurial ecosystems, is a clear picture and understanding of the current situation of entrepreneurial ecosystems at a regional and local level and in particular who are the stakeholders, including the entrepreneurs, their motives, opportunities and problems. The understanding of the stakeholders of regional entrepreneurial ecosystems will play a role in shaping the teaching material and meeting the needs of the local and regional entrepreneurship (Ierapetritis 2017).

The shaping of a framework of academic motives and evaluation that will also include the participation in actions aiming at the promotion of the regional entrepreneurial ecosystem can further increase the interest of the members of the academic community. At the same time, it is required to plan and utilize the appropriate funding instruments towards this direction, which will enable the cooperation between various institutions having knowledge and other resources and representing different fields of knowledge, including the fields of social and humanistic sciences (e.g., Horizon 2020, a EU Research and Innovation programme).

By taking initiatives for the creation of relevant business infrastructure in combination with the establishment and operation of business hubs, business accelerators and offices for the transfer of know-how, Universities can shape a favorable environment for the establishment of start-ups but also for the presentation of successful examples of start-ups.

A more active and substantial participation of Universities in the methods and tools of the Strategic Smart Specialization, both during the planning and re-planning of the Regional Strategy (see processes for Entrepreneurial Discovery) and during the implementation of the necessary actions, will strengthen the role and integration of Universities in their own regional entrepreneurial ecosystems. Moreover, it is particularly useful to conduct field researches in regular intervals which will be addressed to the members of the management of businesses that in the past have cooperated with Universities and members of the academic community of Universities. This allows identifying the obstacles and 
opportunities of Universities to participate in and contribute to regional entrepreneurial ecosystems within the light of the different types of University engagement proposed in the relevant international bibliography (Boucher et al. 2003).

Some more specialized policy suggestions, based on both the aforementioned basic classification of the Greek Universities and the analysis of the survey data: Single-Player Universities in peripheral Regions should enrich their actions by incorporating: (i) capacity boosting actions aiming at acquiring new skills and experiences as well as promoting a creative spirit and innovation skills (e.g., "nurseries of ideas") as these fields lag behind compared to the other University groups; (ii) buffering actions, especially for the creation of low-cost working spaces (incubators) that the Universities of this particular group did not operate between 2011 and 2015; and (iii) bridging actions aiming at a. creating networks and high performing cooperation projects with local enterprises as well as with businesses located in the core regions that have recorded higher performances in entrepreneurship and innovation and $b$. finding alternative means of financing, such as "business angels" and high risk venture capital funds, etc. Concurrently, it is suggested to deal with any malfunctions related to the geographic distribution and access problems faced by some students of those University Faculties that operate in the periphery (insular and/or mountainous areas). Finally, for the sustainable operation of the Units, regardless of their funding through the Structural Funds, finding resources and alternative means of financing is suggested.

As regards the Traditional Universities in Core Regions, some steps are suggested for a more effective information of the students on entrepreneurship and innovation, operation of Innovation and Entrepreneurship Units, actions as well as on the advantages from student participation in them. The enrichment of the actions with buffering actions, especially for the establishment of incubators aiming at creating networks and high performing cooperation projects with local business as well as at finding alternative sources of financing, such as "business angels" and high-risk venture capital funds, etc., is expected to contribute significantly to the creation of human resources. Strengthening the participation of students, through the identification and stressing of converging ways and fields of knowledge between the Faculties for Humanistic and Social Sciences and the knowledge and skills acquired by means of entrepreneurial training, is crucial.

The promotion of the contribution of the Greek Universities that belong to the group of the Multiplayer Universities in Peripheral Regions presupposes the development of business development actions in the teaching and learning, aiming at the cooperation between the administrations of the Institutes and the students of different Universities that are located in the same Region.

Moreover, the enrichment of the actions with (i) bridging actions, aiming at creating networking and high performing cooperation projects with local businesses but also with businesses located in core regions that have recorded higher performances in entrepreneurship and innovation; and meeting alternative means of financing, such as "business angels" and high risk venture capital funds, etc., and (ii) buffering actions aiming mainly at creating incubators and co-working spaces, which is necessary for solving the restricted access to core regions. Positive actions in the same direction are also the steps for more effective information of the students on entrepreneurship and innovation, operation of Innovation and Entrepreneurship Units, actions as well as on the advantages from student participation in them. Last but not least, it is of crucial importance to strengthen the participation of students through the identification and stressing of converging ways and fields of knowledge between the Faculties for Humanistic and Social Sciences and the knowledge and skills acquired by means of business training.

Funding: This research received no external funding.

Acknowledgments: The author would like to thank the anonymous reviewers for their precious comments and recommendations to improve the content and form of this paper.

Conflicts of Interest: The author declares no conflict of interest. 


\section{Appendix A}

Table A1. R\&D expenses in the field of Higher Education (in million euros and \% of the GDP).

\begin{tabular}{lccccccc}
\hline & $\mathbf{2 0 1 1}$ & $\mathbf{2 0 1 2}$ & $\mathbf{2 0 1 3}$ & $\mathbf{2 0 1 4}$ & $\mathbf{2 0 1 5}$ & $\mathbf{2 0 1 6}$ & $\mathbf{2 0 1 7}$ \\
\hline Higher Education Sector (million euros) & 559.5 & 534.3 & 548.6 & 553.2 & 643.8 & 559.4 & 577.7 \\
Total (million euros) & 1391.2 & 1337.6 & 1465.7 & 1488.7 & 1703.8 & 1754.2 & 2033 \\
Higher Education Sector (\% of the GDP) & 0.27 & 0.28 & 0.3 & 0.32 & 0.37 & 0.32 & 0.32 \\
Total (\% of the GDP) & 0.67 & 0.7 & 0.81 & 0.83 & 0.97 & 1.01 & 1.14 \\
\hline
\end{tabular}

Source: National Documentation Centre (http://metrics.ekt.gr/statistica-etak/databases, data code: D1, D2.

Table A2. R\&D expenses in the field of Tertiary and Post-Tertiary Education per region in Greece (in million euros).

\begin{tabular}{lccccccc}
\hline & $\mathbf{2 0 0 1}$ & $\mathbf{2 0 0 3}$ & $\mathbf{2 0 0 5}$ & $\mathbf{2 0 1 1}$ & $\mathbf{2 0 1 3}$ & $\mathbf{2 0 1 5}$ & $\mathbf{2 0 1 6}$ \\
\hline Eastern Macedonia \& Thrace & 18.78 & 18 & 21.49 & 28.53 & 23.42 & 31.43 & 28.96 \\
Central Macedonia & 85.37 & 86 & 96.98 & 103.98 & 97.29 & 100.94 & 77.59 \\
Western Macedonia & 0.61 & 4 & 2.96 & 5.94 & 10.11 & 6.63 & 5.47 \\
Epirus & 23.90 & 22 & 28.65 & 31.49 & 28.34 & 36.39 & 34.28 \\
Thessaly & 12.86 & 19 & 26.85 & 29.66 & 31.85 & 38.41 & 37.46 \\
Ionian Islands & 2.52 & 3 & 4.45 & 3.36 & 4.59 & 9.10 & 5.41 \\
Western Greece & 42.87 & 54 & 43.50 & 56.58 & 51.13 & 62.01 & 60.48 \\
Central Greece & 0.18 & 0 & 1.39 & 2.34 & 3.96 & 6.63 & 4.40 \\
Peloponnese & 0.05 & 0 & 22.39 & 6.84 & 10.03 & 10.10 & 5.88 \\
Attica & 161.67 & 199 & 239.62 & 222.89 & 210.33 & 269.85 & 228.57 \\
North Aegean & 6.17 & 9 & 11.67 & 11.19 & 16.57 & 10.83 & 7.86 \\
South Aegean & 2.55 & 4 & 5.91 & 5.12 & 6.26 & 3.99 & 2.92 \\
Crete & 24.95 & 37 & 41.86 & 51.58 & 54.72 & 57.46 & 60.07 \\
GREECE & 382.50 & 456.77 & 547.72 & 559.53 & 548.60 & 643.77 & 559.35 \\
\hline
\end{tabular}

Source: National Documentation Centre, www.ekt.gr.

Table A3. R\&D staff in the field of Tertiary and Post-Tertiary Education per region in Greece (in number of persons).

\begin{tabular}{lcccccc}
\hline & $\mathbf{2 0 0 1}$ & $\mathbf{2 0 0 3}$ & $\mathbf{2 0 0 5}$ & $\mathbf{2 0 1 1}$ & $\mathbf{2 0 1 3}$ & $\mathbf{2 0 1 5}$ \\
\hline Eastern Macedonia \& Thrace & 1487 & 1321 & 2025 & 3044 & 3470 & 2987 \\
Central Macedonia & 8781 & 7172 & 9193 & 8235 & 10,286 & 9414 \\
Western Macedonia & 34 & 338 & 295 & 823 & 599 & 648 \\
Epirus & 2787 & 1746 & 2697 & 2665 & 3441 & 3077 \\
Thessaly & 1054 & 2102 & 1601 & 4864 & 2856 & 2776 \\
Ionian Islands & 187 & 217 & 298 & 376 & 701 & 757 \\
Western Greece & 3777 & 3377 & 2636 & 3300 & 4446 & 4886 \\
Central Greece & 15 & 24 & 163 & 252 & 762 & 590 \\
Peloponnese & 0 & 36 & 969 & 614 & 856 & 939 \\
Attica & 13,117 & 14,644 & 16,777 & 15,555 & 20,487 & 23,899 \\
North Aegean & 349 & 621 & 619 & 1517 & 1386 & 1003 \\
South Aegean & 146 & 265 & 313 & 693 & 784 & 550 \\
Crete & 1773 & 3225 & 2900 & 4410 & 4528 & 3941 \\
GREECE & 33,507 & 35,088 & 40,486 & 46,348 & 54,602 & 55,467 \\
\hline
\end{tabular}

Source: National Documentation Centre, www.ekt.gr. 
Table A4. Completion of the economic and physical subject of the Innovation and Entrepreneurship Units operated by the Greek Higher Education Institutes over the period 2011-2015.

\begin{tabular}{|c|c|c|c|c|c|c|}
\hline & Higher Education Institute & Initial Budget & $\begin{array}{c}\text { Total Expenses of } \\
\text { the Action }\end{array}$ & $\begin{array}{l}\text { Initial Benefit } \\
\text { Students According } \\
\text { to the Programme }\end{array}$ & $\begin{array}{l}\text { Benefiting Students } \\
\text { According to the } \\
\text { Programme }\end{array}$ & $\begin{array}{c}\text { Real Benefiting } \\
\text { Students }\end{array}$ \\
\hline 1 & Athens School of Fine Arts & 170,190 & 110,196 & & 600 & 388 \\
\hline 2 & Aristotle University of Thessaloniki & 376,694 & 363,554 & 1250 & 1260 & 1271 \\
\hline 3 & Higher Institute of Pedagogic and Technological Education "ASPAITE" & 188,600 & 157,087 & 800 & 800 & 1177 \\
\hline 4 & Agricultural University of Athens & 270,396 & 262,482 & 405 & 405 & 327 \\
\hline 5 & Democritus University of Thrace & 411,167 & 401,707 & 3000 & 3000 & 3036 \\
\hline 6 & International Hellenic University & 129,332 & 103,458 & 550 & 550 & 1064 \\
\hline 7 & National and Kapodistrian University of Athens & 604,367 & 457,652 & 2500 & 2500 & 3000 \\
\hline 8 & National Technical University of Athens & 466,355 & 430,387 & 2000 & 2000 & 5476 \\
\hline 9 & Hellenic Open University & 386,081 & 350,625 & 10,000 & 10,000 & 11,459 \\
\hline 10 & Ionian University & 208,061 & 205,379 & 1000 & 1000 & 1000 \\
\hline 11 & Athens University of Economics & 415,508 & 413,461 & 4200 & 4200 & 6113 \\
\hline 12 & University of the Aegean & 398,971 & 329,623 & 2500 & 2500 & 5010 \\
\hline 13 & University of Western Macedonia & 228,592 & 226,883 & 935 & 935 & 1088 \\
\hline 14 & University of Thessaly & 401,362 & 399,523 & 2380 & 2380 & 3006 \\
\hline 15 & Ioannina University & 240,480 & 227,477 & 1050 & 1050 & 1401 \\
\hline 16 & University of Crete & 86,900 & 83,391 & 1200 & 1200 & 1696 \\
\hline 17 & University of Macedonia & 321,999 & 321,112 & 1260 & 1260 & 1260 \\
\hline 18 & Patras University & 442,523 & 228,288 & 1100 & 1100 & 1693 \\
\hline 19 & Piraeus University & 257,599 & 254,614 & 1700 & 1700 & 1680 \\
\hline 20 & University of the Peloponnese & 163,476 & 137,260 & 900 & 900 & 900 \\
\hline 21 & University of Central Greece & 187,697 & 124,750 & 350 & 350 & 470 \\
\hline 22 & Panteion University & 111,940 & 107,900 & 200 & 200 & 196 \\
\hline \multirow[t]{2}{*}{23} & Technical University of Crete & 231,640 & 231,232 & 900 & 900 & 900 \\
\hline & TOTAL & $6,699,930$ & $5,928,042$ & 40,180 & 40,790 & 53,611 \\
\hline
\end{tabular}

Source: Processing of data made available from the Managing Authority of the Operational Programme, "Human Resources Development, Education and Lifelong Learning", 2018. 
Table A5. Students' capacity-boosting action through Innovation and Entrepreneurship Units.

\begin{tabular}{|c|c|c|c|c|c|c|c|c|c|c|c|c|}
\hline & Higher Education Institute & $\begin{array}{c}\text { Models of } \\
\text { Business Plans }\end{array}$ & $\begin{array}{c}\text { Nursery of } \\
\text { Ideas }\end{array}$ & $\begin{array}{l}\text { Book } \\
\text { Purchase }\end{array}$ & Journals & Consulting-Guidance & Case Studies & $\begin{array}{l}\text { Operation of } \\
\text { Entrepreneurship } \\
\text { Workshop }\end{array}$ & Help Desk & $\begin{array}{l}\text { Creation of } \\
\text { IT System }\end{array}$ & $\begin{array}{c}\text { Documentation } \\
\text { Centre }\end{array}$ & $\mathbf{F}$ \\
\hline 1 & Athens School of Fine Arts & & & & & $\sqrt{ }$ & & & & & & 1 \\
\hline 2 & Aristotle University of Thessaloniki & & & & & & & $\sqrt{ }$ & & $\sqrt{ }$ & & 2 \\
\hline 3 & $\begin{array}{l}\text { Higher Institute of Pedagogic and Technological } \\
\text { Education "ASPAITE" }\end{array}$ & & & & & $\sqrt{ }$ & & & & & & 1 \\
\hline 4 & Agricultural University of Athens & & & & & $\sqrt{ }$ & $\sqrt{ }$ & & & & & 2 \\
\hline 5 & Democritus University of Thrace & & & $\sqrt{ }$ & & $\sqrt{ }$ & & & & & & 2 \\
\hline 6 & International Hellenic University & & & & & $\sqrt{ }$ & $\sqrt{ }$ & $\sqrt{ }$ & & & & 3 \\
\hline 7 & National and Kapodistrian University of Athens & & & & & $\sqrt{ }$ & & & & $\sqrt{ }$ & & 2 \\
\hline 8 & National Technical University of Athens & & & & & & $\sqrt{ }$ & $\sqrt{ }$ & & & $\sqrt{ }$ & 3 \\
\hline 9 & Hellenic Open University & & & & & $\sqrt{ }$ & & & & $\sqrt{ }$ & & 2 \\
\hline 10 & Ionian University & & & & & $\sqrt{ }$ & $\sqrt{ }$ & & & & & 2 \\
\hline 11 & Athens University of Economics & $\sqrt{ }$ & & & & $\sqrt{ }$ & $\sqrt{ }$ & & $\sqrt{ }$ & & & 4 \\
\hline 12 & University of the Aegean & & & & & & $\sqrt{ }$ & & & $\sqrt{ }$ & & 2 \\
\hline 13 & University of Western Macedonia & & & & & $\sqrt{ }$ & & & & & & 1 \\
\hline 14 & University of Thessaly & & & & & $\sqrt{ }$ & & & & & & 1 \\
\hline 15 & Ioannina University & & & $\sqrt{ }$ & $\sqrt{ }$ & $\sqrt{ }$ & & & & $\sqrt{ }$ & & 4 \\
\hline 16 & University of Crete & & & & & $\sqrt{ }$ & $\sqrt{ }$ & & & $\sqrt{ }$ & & 3 \\
\hline 17 & University of Macedonia & & & & & $\sqrt{ }$ & $\sqrt{ }$ & $\sqrt{ }$ & & $\sqrt{ }$ & & 4 \\
\hline 18 & Patras University & & & & & $\sqrt{ }$ & $\sqrt{ }$ & $\sqrt{ }$ & & $\sqrt{ }$ & & 4 \\
\hline 19 & Piraeus University & & & & & $\sqrt{ }$ & $\sqrt{ }$ & $\sqrt{ }$ & & $\sqrt{ }$ & & 4 \\
\hline 20 & University of the Peloponnese & $\sqrt{ }$ & & & & $\sqrt{ }$ & $\sqrt{ }$ & & & & & 3 \\
\hline 21 & University of Central Greece & & & & & & & & & $\sqrt{ }$ & & 1 \\
\hline 22 & Panteion University & $\sqrt{ }$ & & & & $\sqrt{ }$ & & & & $\sqrt{ }$ & & 3 \\
\hline \multirow[t]{3}{*}{23} & Technical University of Crete & & $\sqrt{ }$ & & & $\sqrt{ }$ & & & & & & 2 \\
\hline & TOTAL & 3 & 1 & 2 & 1 & 19 & 11 & 6 & 1 & 11 & 1 & \\
\hline & $\%$ & 13.0 & 4.3 & 8.7 & 4.3 & 82.6 & 47.8 & 26.1 & 4.3 & 47.8 & 4.3 & \\
\hline
\end{tabular}

Source: Processing of data related to the incorporation of the above Universities and the amending deed available from the Managing Authority of the Operational Programme, "Human Resources Development, Education and Lifelong Learning", 2018. 
Table A6. Students' bridging actions through the Innovation and Entrepreneurship Units.

\begin{tabular}{|c|c|c|c|c|c|c|c|c|c|c|c|c|}
\hline & Higher Education Institute & $\begin{array}{l}\text { Invitation of } \\
\text { Speakers }\end{array}$ & $\begin{array}{c}\text { Open } \\
\text { Seminars }\end{array}$ & $\begin{array}{l}\text { Website-IT } \\
\text { System }\end{array}$ & Visits & $\begin{array}{l}\text { Informative } \\
\text { Seminars }\end{array}$ & $\begin{array}{l}\text { Presentation-Diffusion } \\
\text { of Results (Publicity) }\end{array}$ & $\begin{array}{l}\text { Participation in } \\
\text { Conferences }\end{array}$ & $\begin{array}{c}\text { Awarding } \\
\text { Ceremonies-Contact } \\
\text { to Productive Entities }\end{array}$ & $\begin{array}{c}\text { Promotion by } \\
\text { Means of } \\
\text { Evening Classes }\end{array}$ & $\begin{array}{l}\text { Exhibiting } \\
\text { Area }\end{array}$ & $\mathbf{F}$ \\
\hline 1 & Athens School of Fine Arts & & $\sqrt{ }$ & $\sqrt{ }$ & & & & & & & $\sqrt{ }$ & 3 \\
\hline 2 & Aristotle University of Thessaloniki & & $\sqrt{ }$ & & & & & & & & & 1 \\
\hline 3 & $\begin{array}{l}\text { Higher Institute of Pedagogic and } \\
\text { Technological Education "ASPAITE" }\end{array}$ & & $\sqrt{ }$ & $\sqrt{ }$ & & & & & & & & 2 \\
\hline 4 & Agricultural University of Athens & & & $\sqrt{ }$ & $\sqrt{ }$ & & & & $\sqrt{ }$ & & & 3 \\
\hline 5 & Democritus University of Thrace & & $\sqrt{ }$ & $\sqrt{ }$ & $\sqrt{ }$ & & $\sqrt{ }$ & & & & & 4 \\
\hline 6 & International Hellenic University & & & $\sqrt{ }$ & & & & & & & & 1 \\
\hline 7 & $\begin{array}{l}\text { National and Kapodistrian University } \\
\text { of Athens }\end{array}$ & & $\sqrt{ }$ & $\sqrt{ }$ & $\sqrt{ }$ & & & & & & & 3 \\
\hline 8 & National Technical University of Athens & & $\sqrt{ }$ & $\sqrt{ }$ & $\sqrt{ }$ & & $\sqrt{ }$ & $\sqrt{ }$ & & & & 5 \\
\hline 9 & Hellenic Open University & & $\sqrt{ }$ & $\sqrt{ }$ & & $\sqrt{ }$ & $\sqrt{ }$ & & & & & 4 \\
\hline 10 & Ionian University & & $\sqrt{ }$ & $\sqrt{ }$ & $\sqrt{ }$ & & $\sqrt{ }$ & & & & & 4 \\
\hline 11 & Athens University of Economics & $\sqrt{ }$ & $\sqrt{ }$ & $\sqrt{ }$ & & & $\sqrt{ }$ & & & & & 4 \\
\hline 12 & University of the Aegean & & $\sqrt{ }$ & $\sqrt{ }$ & $\sqrt{ }$ & & $\sqrt{ }$ & & & $\sqrt{ }$ & & 5 \\
\hline 13 & University of Western Macedonia & & $\sqrt{ }$ & & & & & & & & & 1 \\
\hline 14 & University of Thessaly & & $\sqrt{ }$ & $\sqrt{ }$ & $\sqrt{ }$ & & $\sqrt{ }$ & & & & & 4 \\
\hline 15 & Ioannina University & & & $\sqrt{ }$ & $\sqrt{ }$ & $\sqrt{ }$ & & & & & & 3 \\
\hline 16 & University of Crete & & & & $\sqrt{ }$ & & & & & & & 1 \\
\hline 17 & University of Macedonia & & $\sqrt{ }$ & $\sqrt{ }$ & $\sqrt{ }$ & & $\sqrt{ }$ & & & & & 4 \\
\hline 18 & Patras University & & $\sqrt{ }$ & $\sqrt{ }$ & $\sqrt{ }$ & & $\sqrt{ }$ & & & & & 4 \\
\hline 19 & Piraeus University & & $\sqrt{ }$ & $\sqrt{ }$ & $\sqrt{ }$ & & $\sqrt{ }$ & & & & & 4 \\
\hline 20 & University of the Peloponnese & & $\sqrt{ }$ & $\sqrt{ }$ & & & $\sqrt{ }$ & & & & & 3 \\
\hline 21 & University of Central Greece & & & $\sqrt{ }$ & & $\sqrt{ }$ & & & & & & 2 \\
\hline 22 & Panteion University & & & $\sqrt{ }$ & $\sqrt{ }$ & & $\sqrt{ }$ & & & & & 3 \\
\hline 23 & Technical University of Crete & & $\sqrt{ }$ & & $\sqrt{ }$ & & $\sqrt{ }$ & & & & & 3 \\
\hline & TOTAL & 1 & 17 & 19 & 14 & 3 & 13 & 1 & 1 & 1 & 1 & \\
\hline & $\%$ & 4.3 & 73.9 & 82.6 & 60.9 & 13.0 & 56.5 & 4.3 & 4.3 & 4.3 & 4.3 & \\
\hline
\end{tabular}

Source: Processing of data related to the incorporation of the above Universities and the amending deed available from the Managing Authority of the Operational Programme "Human Resources Development, Education and Lifelong Learning", 2018 
Table A7. Students' buffering actions through the Innovation and Entrepreneurship Units.

\begin{tabular}{|c|c|c|c|c|c|c|c|c|c|c|c|c|c|}
\hline & Higher Education Institute & Classes & $\begin{array}{l}\text { Teaching } \\
\text { Material }\end{array}$ & Book-Publication & $\begin{array}{c}\text { Business } \\
\text { Games }\end{array}$ & Research/Study & $\begin{array}{l}\text { Business Plans for } \\
\text { Virtual Businesses }\end{array}$ & $\begin{array}{c}\text { Creation of an } \\
\text { Entrepreneurship } \\
\text { Guide } \\
\text { (Business Plan) }\end{array}$ & Equipment & Software & $\begin{array}{c}\text { Experimental } \\
\text { Operation of } \\
\text { Business Nursery }\end{array}$ & $\begin{array}{l}\text { Follow up of the } \\
\text { Beneficiaries }\end{array}$ & $\mathbf{F}$ \\
\hline 1 & Athens School of Fine Arts & $\sqrt{ }$ & $\sqrt{ }$ & & & & $\sqrt{ }$ & & & & & & 3 \\
\hline 2 & Aristotle University of Thessaloniki & $\sqrt{ }$ & $\sqrt{ }$ & & & & & & & & & & 2 \\
\hline 3 & $\begin{array}{l}\text { Higher Institute of Pedagogic and } \\
\text { Technological Education "ASPAITE" }\end{array}$ & $\sqrt{ }$ & $\sqrt{ }$ & & & & & & & & & & 2 \\
\hline 4 & Agricultural University of Athens & $\sqrt{ }$ & $\sqrt{ }$ & & & & & & & & & & 2 \\
\hline 5 & Democritus University of Thrace & $\sqrt{ }$ & & & & & & & $\sqrt{ }$ & $\sqrt{ }$ & & $\sqrt{ }$ & 4 \\
\hline 6 & International Hellenic University & $\sqrt{ }$ & $\sqrt{ }$ & & & & & & & & & & 2 \\
\hline 7 & $\begin{array}{l}\text { National and Kapodistrian University } \\
\text { of Athens }\end{array}$ & $\sqrt{ }$ & $\sqrt{ }$ & & & & $\checkmark$ & & & & & $\sqrt{ }$ & 4 \\
\hline 8 & $\begin{array}{l}\text { National Technical University } \\
\text { of Athens }\end{array}$ & $\sqrt{ }$ & $\sqrt{ }$ & & & $\sqrt{ }$ & & & & & $\sqrt{ }$ & $\sqrt{ }$ & 5 \\
\hline 9 & Hellenic Open University & $\sqrt{ }$ & $\sqrt{ }$ & & & & & & & & & $\sqrt{ }$ & 3 \\
\hline 10 & Ionian University & $\sqrt{ }$ & $\sqrt{ }$ & & & & & & & & & & 2 \\
\hline 11 & $\begin{array}{l}\text { Athens University of Business and } \\
\text { Economics }\end{array}$ & $\sqrt{ }$ & $\sqrt{ }$ & $\sqrt{ }$ & $\sqrt{ }$ & $\sqrt{ }$ & $\sqrt{ }$ & & $\sqrt{ }$ & & & & 7 \\
\hline 12 & University of the Aegean & $\sqrt{ }$ & & & $\sqrt{ }$ & & $\sqrt{ }$ & & & & & & 3 \\
\hline 13 & University of Western Macedonia & $\sqrt{ }$ & $\sqrt{ }$ & & & & & & & & & & 2 \\
\hline 14 & University of Thessaly & $\sqrt{ }$ & $\sqrt{ }$ & & & & & & & & & & 2 \\
\hline 15 & Ioannina University & $\sqrt{ }$ & $\sqrt{ }$ & & & $\sqrt{ }$ & $\sqrt{ }$ & & & & & & 4 \\
\hline 16 & University of Crete & $\sqrt{ }$ & $\sqrt{ }$ & & & & & & & & & & 2 \\
\hline 17 & University of Macedonia & $\sqrt{ }$ & $\sqrt{ }$ & & & & & & & & & & 2 \\
\hline 18 & Patras University & $\sqrt{ }$ & $\sqrt{ }$ & & & & $\sqrt{ }$ & & & & & & 3 \\
\hline 19 & Piraeus University & $\sqrt{ }$ & $\sqrt{ }$ & & & & $\sqrt{ }$ & & & & & & 3 \\
\hline 20 & University of the Peloponnese & $\sqrt{ }$ & $\sqrt{ }$ & & & & & & & & & & 2 \\
\hline 21 & University of Central Greece & $\sqrt{ }$ & & & & & & $\sqrt{ }$ & $\sqrt{ }$ & & & & 3 \\
\hline 22 & Panteion University & $\sqrt{ }$ & & & & & & & & & & & 1 \\
\hline \multirow[t]{3}{*}{23} & Technical University of Crete & $\sqrt{ }$ & $\sqrt{ }$ & $\sqrt{ }$ & & & & & & & & & 3 \\
\hline & TOTAL & 23 & 19 & 2 & 2 & 3 & 7 & 1 & 3 & 1 & 1 & 4 & \\
\hline & $\%$ & 100.0 & 82.6 & 8.7 & 8.7 & 13.0 & 30.4 & 4.3 & 13.0 & 4.3 & 4.3 & 17.4 & \\
\hline
\end{tabular}

Source: Processing of data related to the incorporation of the above Universities and the amending deed available from the Managing Authority of the Operational Programme "Human Resources Development, Education and Lifelong Learning", 2018. 
Table A8. Number of students in Greek Universities and real benefitting students of Innovation and Entrepreneurship Units 2011-2015.

\begin{tabular}{|c|c|c|c|c|c|c|c|}
\hline & 2011/12 & $2012 / 13$ & 2013/14 & 2014/15 & 2011-15 AVG & $\begin{array}{c}\text { Real Benefiting } \\
\text { Students 2011-2015 }\end{array}$ & $\%$ \\
\hline Total & 352.790 & 350.671 & 367.246 & 387.055 & 364.441 & 39.911 & 0.11 \\
\hline National and Kapodistrian University of Athens & 92.159 & 78.242 & 90.889 & 85.961 & 86.813 & 3.000 & 0.03 \\
\hline University of the Aegean & 11.066 & 12.382 & 13.160 & 13.834 & 12.611 & 5.010 & 0.40 \\
\hline University of Thessaly & 8.985 & 9.326 & 10.889 & 11.281 & 10.120 & 3.006 & 0.30 \\
\hline Aristotle University of Thessaloniki & 65.963 & 65.629 & 65.672 & 64.568 & 65.458 & 1.271 & 0.02 \\
\hline Democritus University of Thrace & 18.821 & 21.240 & 21.067 & 21.651 & 20.695 & 3.036 & 0.15 \\
\hline Ionian University & 3.560 & 3.620 & 3.941 & 4.039 & 3.790 & 1.000 & 0.26 \\
\hline Ioannina University & 16.277 & 16.431 & 18.118 & 16.973 & 16.950 & 1.401 & 0.08 \\
\hline University of Crete & 14.694 & 16.135 & 15.739 & 16.840 & 15.852 & 1.696 & 0.11 \\
\hline Patras University & 22.630 & 24.028 & 26.707 & 29.612 & 25.744 & 1.693 & 0.07 \\
\hline Athens University of Business and Economics & 18.384 & 18.494 & 18.445 & 18.556 & 18.470 & 6.113 & 0.33 \\
\hline Panteion University & 11.803 & 16.536 & 16.886 & 18.496 & 15.930 & 196 & 0.01 \\
\hline Piraeus University & 20.305 & 19.800 & 18.971 & 20.129 & 19.801 & 1.680 & 0.08 \\
\hline University of Macedonia & 15.235 & 15.757 & 16.029 & 14.825 & 15.462 & 1.260 & 0.08 \\
\hline Agricultural University of Athens & 4.668 & 4.813 & 5.070 & 5.416 & 4.992 & 327 & 0.07 \\
\hline Athens School of Fine Arts & 1.381 & 1.316 & 1.444 & 1.525 & 1.417 & 388 & 0.27 \\
\hline University of the Peloponnese & 3.988 & 4.578 & 5.200 & 5.785 & 4.888 & 900 & 0.18 \\
\hline University of Western Macedonia & 3.165 & 2.959 & 2.165 & 2.240 & 2.632 & 1.088 & 0.41 \\
\hline Technical University of Crete & 3.418 & 3.795 & 4.034 & 4.744 & 3.998 & 900 & 0.23 \\
\hline National Technical University of Athens & 12.274 & 11.338 & 11.158 & 12.162 & 11.733 & 5.476 & 0.47 \\
\hline University of Central Greece & 629 & 787 & - & & 708 & 470 & 0.66 \\
\hline
\end{tabular}

Source: ELSTAT, 2012-2019. 
Table A9. Greek Universities (Basic Characteristics and Structure) for the academic period 2019-2020.

\begin{tabular}{|c|c|c|c|c|c|c|}
\hline University & year & Region (NUTS2) & Region (NUTS3) & Region (LAU1) & Schools & Departments \\
\hline \multirow{5}{*}{ University of the Aegean } & \multirow{5}{*}{1984} & \multirow{5}{*}{$\begin{array}{l}\text { North Aegean \& } \\
\text { South Aegean }\end{array}$} & Lesvos & Mytilene & Social Sciences, Environment. & \multirow{5}{*}{18} \\
\hline & & & Chios & Chios & Engineering, Business. & \\
\hline & & & Samos & Samos & Engineering. & \\
\hline & & & Cyclades & Syros & Engineering. & \\
\hline & & & Dodecanese & Rhodes & Humanities. & \\
\hline \multirow{5}{*}{ University of Thessaly } & \multirow{5}{*}{1984} & \multirow{4}{*}{ Thessaly } & Volos & Volos & $\begin{array}{l}\text { Engineering, Humanities and Social Sciences, Agricultural Sciences, Economic and Management Sciences, } \\
\text { Agricultural Sciences. }\end{array}$ & \multirow{5}{*}{37} \\
\hline & & & Larissa & Larissa & Health Sciences, Economic and Management Sciences, Technology, Health Sciences, Agricultural Sciences. & \\
\hline & & & Trikala & Trikala & Physical Education and Sport Science. & \\
\hline & & & Karditsa & Karditsa & Technology, Health Sciences, Agricultural Sciences. & \\
\hline & & Central Greece & Fthiotida & Lamia & Science, Health Sciences. & \\
\hline \multirow{4}{*}{ Democritus University of Thrace } & \multirow{4}{*}{1973} & \multirow{4}{*}{$\begin{array}{l}\text { Eastern Macedonia } \\
\text { and Thrace }\end{array}$} & Xanthi & Xanthi & Engineering. & \multirow{4}{*}{20} \\
\hline & & & Alexandroupoli & Alexandroupoli & Education Sciences, Health Sciences. & \\
\hline & & & Komotini & Komotini & Social Political and Economic Sciences, Law, Classics and Humanities, Physical education and Sport Sciences. & \\
\hline & & & Orestiada & Orestiada & Agricultural and Forestry Sciences. & \\
\hline \multirow{5}{*}{ University of Western Macedonia } & \multirow{5}{*}{2003} & \multirow{5}{*}{ Western Macedonia } & Kozani & Kozani & Engineering, Economic Sciences. & \multirow{5}{*}{28} \\
\hline & & & Florina & Florina & Humanities and Social Sciences, Fine Arts, Agricultural Sciences. & \\
\hline & & & Kastoria & Kastoria & Economic Sciences, Sciences. & \\
\hline & & & Grevena & Grevena & School of Economic Sciences. & \\
\hline & & & Kozani & Ptolemaida & Health Sciences. & \\
\hline \multirow{5}{*}{ Ionian University } & \multirow{5}{*}{1984} & \multirow{5}{*}{ Ionian Islands } & Corfu & Corfu & History \& Translation-Interpreting, Information Science \& Informatics, Economic Sciences. & \multirow{5}{*}{12} \\
\hline & & & Kefalonia & Argostoli & Information Science \& Informatics, Environmental Sciences. & \\
\hline & & & Kefalonia & Lixouri & Music \& Audiovisual Arts. & \\
\hline & & & Zakynthos & Zakynthos & Environmental Sciences. & \\
\hline & & & Lefkada & Lefkada & Economic Sciences. & \\
\hline \multirow{2}{*}{ University of Central Greece } & \multirow{2}{*}{2003} & \multirow[b]{2}{*}{ Central Greece } & Fthiotida & Lamia & Applied Sciences. & \multirow[b]{2}{*}{2} \\
\hline & & & Viotia & Levadia & Economy and Administration. & \\
\hline \multirow{5}{*}{ University of the Peloponnese } & \multirow{5}{*}{2000} & \multirow{5}{*}{ Peloponnese } & Korinth & Korinth & Social and Political Sciences. & \multirow{5}{*}{22} \\
\hline & & & Arcadia & Tripolis & Economy, Management and Informatics. & \\
\hline & & & Messinia & Kalamata & Humanities and Cultural Studies. & \\
\hline & & & Argolida & Nafplio & Arts. & \\
\hline & & & Laconia & Sparta & Human Movement and Quality of Life Science. & \\
\hline \multirow{2}{*}{$\begin{array}{l}\text { National and Kapodistrian } \\
\text { University of Athens }\end{array}$} & 1837 & Attica & Athens & Athens & $\begin{array}{l}\text { Economics and Political Sciences, Education, Health Sciences, Law, Philosophy, Physical Education and Sport Science, } \\
\text { Theology, Science. }\end{array}$ & 43 \\
\hline & & Central Greece & Evoia & Chalkida & Agricultural Development and Sustainability, Science. & \\
\hline
\end{tabular}


Table A9. Cont.

\begin{tabular}{|c|c|c|c|c|c|c|}
\hline University & year & Region (NUTS2) & Region (NUTS3) & Region (LAU1) & Schools & Departments \\
\hline $\begin{array}{l}\text { Aristotle University of } \\
\text { Thessaloniki }\end{array}$ & 1925 & Central Macedonia & Thessaloniki & Thessaloniki & Theology, Philosophy, Sciences, Law, Economic and Political Sciences, Health Sciences. & 41 \\
\hline Piraeus University & 1938 & Attica & Pireaus & Pireaus & $\begin{array}{l}\text { Economics Business and International Studies, Maritime and Industrial Studies, Finance and Statistics, Information } \\
\text { and Communication Technologies. }\end{array}$ & 10 \\
\hline \multirow{4}{*}{ Agricultural University of Athens } & \multirow{4}{*}{1920} & Attica & $\begin{array}{l}\text { Central Area } \\
\text { of Athens }\end{array}$ & Athens & $\begin{array}{l}\text { Plant Sciences, Animal Biosciences, Environment and Agricultural Engineering, Food and Nutritional Sciences, } \\
\text { Applied Biology and Biotechnology, Applied Economics and Social Sciences. }\end{array}$ & \multirow{4}{*}{14} \\
\hline & & \multirow{3}{*}{ Central Greece } & Viotia & Thiva & Applied Economics and Social Sciences. & \\
\hline & & & Evritania & Karpenissi & Plant Sciences. & \\
\hline & & & Fokida & Amfissa & Applied Economics and Social Sciences. & \\
\hline University of Macedonia & $\begin{array}{l}1990 \\
(1948)\end{array}$ & Central Macedonia & Thessaloniki & Thessaloniki & Economic and Regional Studies, Business Administration, Information Sciences, Social Sciences Humanities and Arts. & 8 \\
\hline Panteion University & 1933 & Attica & Central Athens & Athens & $\begin{array}{l}\text { Economy and Public Administration, Political Science, Social Science, International Studies Communication } \\
\text { and Culture. }\end{array}$ & 9 \\
\hline $\begin{array}{l}\text { Athens University of Business } \\
\text { and Economics }\end{array}$ & 1920 & Attica & Central Athens & Athens & Economic Sciences, Business, Information Sciences and Technology. & 8 \\
\hline $\begin{array}{l}\text { National Technical University } \\
\text { of Athens }\end{array}$ & 1837 & Attica & Central Athens & Athens & $\begin{array}{l}\text { Civil Engineering, Mechanical Engineering, Electrical and Computer Engineering, Architecture, Chemical } \\
\text { Engineering, Rural and Surveying Engineering, Mining and Metallurgical Engineering, Naval Architecture and } \\
\text { Marine Engineering, Applied Mathematical and Physical Sciences. }\end{array}$ & 9 \\
\hline Athens School of Fine Arts & 1837 & Attica & Central Athens & Athens & Fine Arts. & 2 \\
\hline Hellenic Open University & 1992 & Western Greece & Achaia & Patras & Social Sciences, Applied Arts, Science \& Technology, Humanities. & 4 \\
\hline University of Crete & 1973 & Crete & $\begin{array}{c}\text { Rethymnon } \\
\text { Heraklion }\end{array}$ & $\begin{array}{l}\text { Rethymnon } \\
\text { Herakleion }\end{array}$ & Philosophy, Education, Social Sciences, Sciences \& Engineering, Medicine. & 16 \\
\hline \multirow{6}{*}{ International University } & \multirow{6}{*}{2005} & \multirow{6}{*}{ Central Macedonia } & Thessaloniki & Thessaloniki & $\begin{array}{l}\text { Economy and Administration, Social Sciences, Health Sciences, Engineering, Geotechnical Sciences, Human Social } \\
\text { and Economic Sciences (Int. Post.Grad.), Science and Technology (Int. Post.Grad.) }\end{array}$ & \multirow{6}{*}{35} \\
\hline & & & Kavala & Kavala & Economy and Administration, Sciences. & \\
\hline & & & Pieria & Katerini & Economy and Administration. & \\
\hline & & & Kilkis & Kilkis & Design Sciences. & \\
\hline & & & Drama & Drama & Geotechnical Sciences. & \\
\hline & & & Serres & Serres & Economy and Administration, Engineering, Design Sciences. & \\
\hline \multirow{6}{*}{ Patras University } & \multirow{6}{*}{1964} & \multirow{6}{*}{ Western Greece } & Achaia & Patras & $\begin{array}{l}\text { Economics \& Business, Engineering, Health Rehabilitation Sciences, Health Sciences, Humanities and Social Sciences, } \\
\text { Legal Sciences, Natural Sciences, Physical Education and Sport Science. }\end{array}$ & \multirow{6}{*}{37} \\
\hline & & & Etoloakarnania & Messolonghi & Agricultural Sciences. & \\
\hline & & & Etoloakarnania & Agrinio & $\begin{array}{l}\text { Agricultural Sciences, } \\
\text { Humanities and Social Sciences. }\end{array}$ & \\
\hline & & & Achaia & Aigio & Health Rehabilitation Sciences. & \\
\hline & & & IIlia & Pyrgos & Humanities and Social Sciences. & \\
\hline & & & Ilia & Amaliada & Agricultural Sciences. & \\
\hline Technical University of Crete & 1977 & Crete & Chania & Chania & $\begin{array}{l}\text { Environmental Engineering, Production Engineering and Management, } \\
\text { Mineral Resources Engineering, Electrical and Computer Engineering, Architecture. }\end{array}$ & 5 \\
\hline \multirow[t]{2}{*}{ Ioannina University } & \multirow[t]{2}{*}{1970} & \multirow[t]{2}{*}{ Epirus } & Ioannina & Ioannina & $\begin{array}{l}\text { Philosophy, Sciences, Health Sciences, Education Sciences, } \\
\text { School of Social Sciences, School of Economic \& Business Sciences. }\end{array}$ & \multirow[t]{2}{*}{26} \\
\hline & & & Arta & Arta & Music Studies, Informatics and Telecommunication, Agricultural Sciences. & \\
\hline
\end{tabular}


Table A10. Number of learning action and Real Benefitting Students of the Innovation and Entrepreneurship Units (2011-2015).

\begin{tabular}{|c|c|c|c|c|c|}
\hline & $\begin{array}{c}\text { Real Benefiting } \\
\text { Students 2011-15 }\end{array}$ & $\begin{array}{l}\text { Buffering } \\
\text { Actions }\end{array}$ & $\begin{array}{l}\text { Capacity-Boosting } \\
\text { Actions }\end{array}$ & $\begin{array}{l}\text { Bridging } \\
\text { Actions }\end{array}$ & Total \\
\hline \multicolumn{6}{|l|}{ Single Player Universities in Peripheral Regions } \\
\hline University of the Aegean & 0.40 & 3 & 2 & 5 & 10 \\
\hline University of Thessaly & 0.30 & 2 & 1 & 4 & 7 \\
\hline Democritus University of Thrace & 0.15 & 4 & 2 & 4 & 10 \\
\hline University of Western Macedonia & 0.41 & 2 & 1 & 1 & 4 \\
\hline Ionian University & 0.26 & 2 & 2 & 4 & 8 \\
\hline University of Central Greece & 0.66 & 3 & 1 & 2 & 6 \\
\hline University of the Peloponnese & 0.18 & 2 & 3 & 3 & 8 \\
\hline Average & 0.34 & 3 & 2 & 3 & 8 \\
\hline \multicolumn{6}{|l|}{ Traditional Universities in Core Regions } \\
\hline National and Kapodistrian University of Athens & 0.03 & 4 & 2 & 3 & 9 \\
\hline Aristotle University of Thessaloniki & 0.02 & 2 & 2 & 1 & 5 \\
\hline Piraeus University & 0.08 & 3 & 4 & 4 & 11 \\
\hline Agricultural University of Athens & 0.07 & 2 & 2 & 3 & 7 \\
\hline University of Macedonia & 0.08 & 2 & 4 & 4 & 10 \\
\hline Panteion University & 0.01 & 1 & 3 & 3 & 7 \\
\hline Athens University of Business and Economics & 0.33 & 7 & 4 & 4 & 15 \\
\hline National Technical University of Athens & 0.47 & 5 & 3 & 5 & 13 \\
\hline Athens School of Fine Arts & 0.27 & 3 & 1 & 3 & 7 \\
\hline Average & 0.15 & 3 & 3 & 3 & 9 \\
\hline \multicolumn{6}{|l|}{ Multiplayer Universities in Peripheral Regions } \\
\hline University of Crete & 0.11 & 2 & 3 & 1 & 6 \\
\hline International University & N/A & 2 & 3 & 1 & 6 \\
\hline Patras University & 0.07 & 3 & 4 & 4 & 11 \\
\hline Technical University of Crete & 0.23 & 3 & 2 & 3 & 8 \\
\hline Ioannina University & 0.08 & 4 & 4 & 3 & 11 \\
\hline Average & 0.12 & 3 & 3 & 3 & 9 \\
\hline Newer Technologically Oriented Universities in Co & egions & & & & \\
\hline
\end{tabular}

Source: Processing of data made available from ELSTAT and the amending deed available from the Managing Authority of the Operational Programme "Human Resources Development, Education and Lifelong Learning", 2018. 
Table A11. Results of the evaluation of the individual actions of the Innovation and Entrepreneurship Units of the period 2011-2015 by the students of the Higher Education Institutes.

\begin{tabular}{|c|c|c|c|c|c|c|c|c|c|c|c|c|c|c|c|}
\hline & & 1 & & 2 & & 3 & & 4 & & 5 & DO & $\begin{array}{l}\text { N/NO } \\
\text { N }\end{array}$ & Total & $(1+2+3)$ & $(4+5)$ \\
\hline Strengthening the knowledge of students in the making of innovative business plans & 3 & $2.3 \%$ & 6 & $4.6 \%$ & 28 & $21.5 \%$ & 52 & $40.0 \%$ & 31 & $23.8 \%$ & 10 & $7.7 \%$ & 130 & $28.5 \%$ & $63.8 \%$ \\
\hline Planning of lectures on innovation and entrepreneurship & 4 & $3.1 \%$ & 1 & $0.8 \%$ & 20 & $15.4 \%$ & 52 & $40.0 \%$ & 46 & $35.4 \%$ & 7 & $5.4 \%$ & 130 & $19.2 \%$ & $75.4 \%$ \\
\hline Selection of teaching staff for the subjects of innovation and entrepreneurship & 5 & $3.8 \%$ & 4 & $3.1 \%$ & 21 & $16.2 \%$ & 52 & $40.0 \%$ & 44 & $33.8 \%$ & 4 & $3.1 \%$ & 130 & $23.1 \%$ & $73.8 \%$ \\
\hline Creation of teaching material for innovation & 3 & $2.3 \%$ & 2 & $1.5 \%$ & 23 & $17.7 \%$ & 60 & $46.2 \%$ & 37 & $28.5 \%$ & 5 & $3.8 \%$ & 130 & $21.5 \%$ & $74.6 \%$ \\
\hline Planning of seminars within the framework of innovation in entrepreneurship & 3 & $2.3 \%$ & 5 & $3.8 \%$ & 19 & $14.6 \%$ & 48 & $36.9 \%$ & 52 & $40.0 \%$ & 3 & $2.3 \%$ & 130 & $20.8 \%$ & $76.9 \%$ \\
\hline Visits to productive entities that incorporate innovations in their operation & 7 & $5.4 \%$ & 6 & $4.6 \%$ & 38 & $29.2 \%$ & 46 & $35.4 \%$ & 26 & $20.0 \%$ & 7 & $5.4 \%$ & 130 & $39.2 \%$ & $55.4 \%$ \\
\hline Consulting, guidance and support for innovation & 4 & $3.1 \%$ & 5 & $3.8 \%$ & 27 & $20.8 \%$ & 44 & $33.8 \%$ & 42 & $32.3 \%$ & 8 & $6.2 \%$ & 130 & $27.7 \%$ & $66.2 \%$ \\
\hline
\end{tabular}

Source: Trek Consulting (2016).

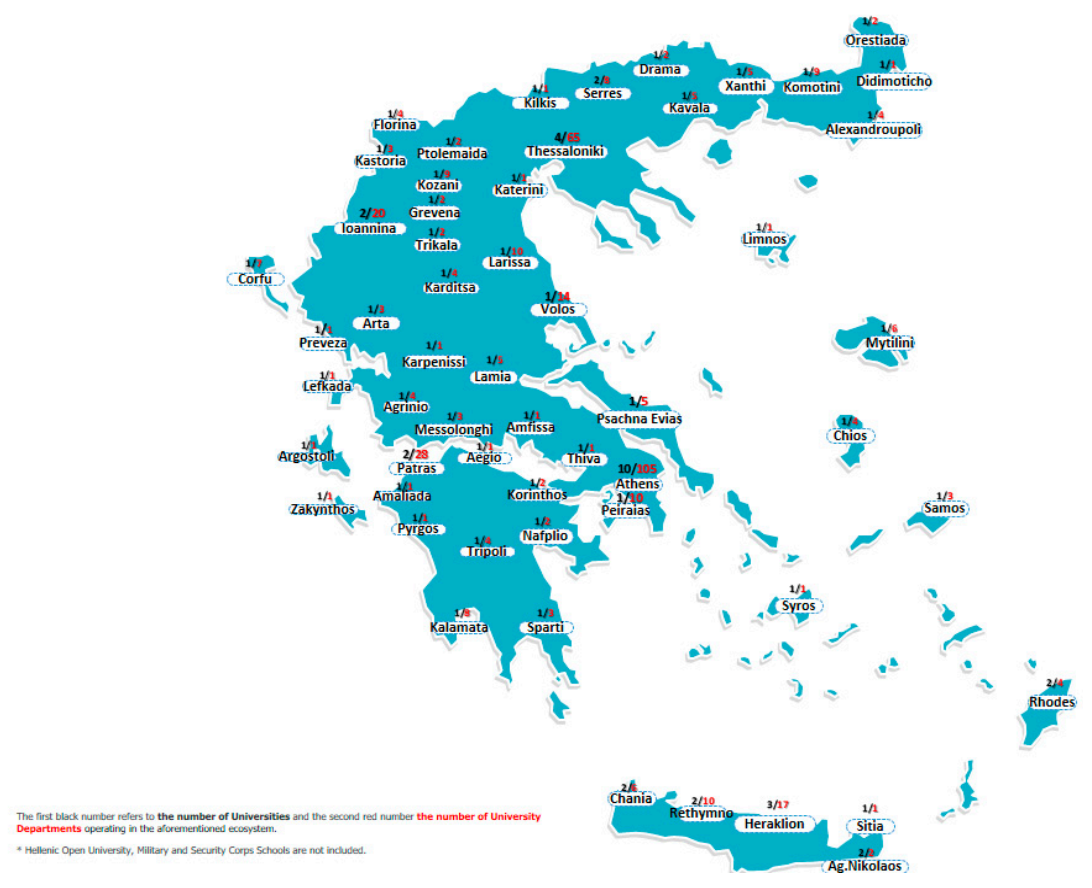

Figure A1. The new geographic distribution of the Tertiary Education in Greece, 2019-2020. Source: Processing of data made available from the Ministry of Education, Research and Religious Affairs, https://www.minedu.gov.gr/katalogos-aei (accessed on 1 June 2019). 


\section{References}

Aalborg University. 2019. Supporting Entrepreneurship at Aalborg University. Available online: www.sea.aau.dk (accessed on 14 September 2019).

Amin, Ash, and Nigel Thrift. 1994. Globalization, Institutions and Regional Development in Europe. Oxford: Oxford University Press.

Audretsch, David B. 2014. From the Entrepreneurial University to the University for the Entrepreneurial Society. Journal of Technology Transfer 39: 313-21. [CrossRef]

Autio, Ekko, and Heikki Rannikko. 2016. Retaining winners: Can policy boost high-growth entrepreneurship? Research Policy 45: 42-55. [CrossRef]

Benneworth, Paul, Rómulo Pinheiro, and James Karlsen. 2017. Strategic Agency and Institutional Change: Investigating the Role of Universities in Regional Innovation Systems (RISs). Regional Studies 51: $235-48$. [CrossRef]

Boucher, Gerry, Cheryl Conway, and Els Van Der Meer. 2003. Tiers of Engagement by Universities in their Region's Development. Regional Studies 37: 887-97. [CrossRef]

Bruneel, Johan, Pablo d'Este, and Ammon Salter. 2010. Investigating the Factors That Diminish the Barriers to University-Industry Collaboration. Research Policy 39: 858-68. [CrossRef]

Carlsson, Bo, Staffan Jacobsson, Magnus Holmén, and Annika Rickne. 2002. Innovation Systems: Analytical and Methodological Issues. Research Policy 31: 233-45. [CrossRef]

Committee of the Region. 2014. Using the Quadruple Helix Approach to Accelerate the Transfer of Research and Innovation Results to Regional Growth. Available online: http://cor.europa.eu/en/documentation/studies/ Documents/quadruplehelix.pdf (accessed on 14 July 2019).

Cooke, Philip, Mikel Gomez Uranga, and Goio Etxebarria. 1997. Regional Innovation Systems: Institutional and Organizational Dimensions. Research Policy 26: 475-91. [CrossRef]

Demola. 2019. The Global University Alliance. Available online: www.demola.net (accessed on 14 September 2019).

DiaNEOsis. 2016. The Impact of Research on Greek Economic Growth. Athens: German Institute for Economic Research, DIW Econ. (In Greek)

EC, and OECD. 2012. A Guiding Framework for Entrepreneurial Universities. Available online: www.oecd.org/site/ cfecpr/EC-OECD\%20entrepreneurial\%20Universities\%20Framework.pdf (accessed on 19 September 2019).

Elena-Pérez, Susana, Eskarne Arregui, and Elisabetta Marinelli. 2017. The Role of Universities in Regional Development Through Smart Specialization Strategies: Evidence from Two Spanish Regions (Catalonia and Navarre). Economiaz 92: 42-67.

EM Lyon Business School. 2019. Entrepreneurship Incubation. Available online: www.em-lyon.com/en/ Entrepreneurship-Incubation (accessed on 14 September 2019).

Ernst-Abbe-Hochhule Jena. 2019. Center for Innovation and Entrepreneurship, University of Applied Sciences Jena. Available online: www.eah-jena.de/de-de/forschung_/Documents/Flyer_CIE_2015.PDF (accessed on 14 September 2019).

Etzkowitz, Henry. 2013. Anatomy of the entrepreneurial university. Social Science Information 52: $486-511$. [CrossRef]

Etzkowitz, Henry, and Loet Leydesdorff. 2000. The Dynamics of Innovation:from National Systems and "Mode 2" to a Triple Helix of University-Industry-Government Relations. Research Policy 29: 109-23. [CrossRef]

European Commission. 2017. Renewed EU Agenda for Higher Education. COM (2017) (247 Final). Brussels: CEC.

European Commission. 2019. European Innovation Scoreboard. Brussels: European Union.

European Innovation Scoreboard. 2019. Greek Profile over Time. Available online: https://interactivetool.eu/EIS/ EIS_2.html\#f (accessed on 14 September 2019).

European University Association. 2014. The Role of Universities in Smart Specialization Strategies. Report on Joint EUA-REGIO/JRC. Brussels: EUA Publications.

Eurostat. 2019. R\&D expenditure in the EU increased slightly to 2.07\% of GDP in 2017, First estimates of Research \& Development expenditure. Newsrelease, January.

Feld, Brad. 2012. Startup Communities: Building an Entrepreneurial Ecosystem in Your City. New York: Wiley.

Fischer, Manfred M., and Peter Nijkamp. 1988. The Role of small firms for regional revitalization. The Annals of Regional Science 1: 28. [CrossRef] 
General Secretariat for Industry. 2016. Report on the Results of the Research "Mapping the Business Needs of Greek Start-Ups Already Existing and in the Process of Being Set Up". Athens: General Directorate for Industrial \& Business Policy, Directorate for the Support of Small and Medium Enterprises Start-Up Greece, Ministry for Economy and Development.

Guerrero, Maribel, and David Urbano. 2010. The Development of an Entrepreneurial University. Journal of Technology Transfer 37: 43-74. [CrossRef]

Guerrero, Maribel, and David Urbano. 2016. The Transformative Role of Universities: Determinants, Impacts, and Challenges. In Entrepreneurial and Innovative Practices in Public Institutions. Applying Quality of Life Research (Best Practices). Edited by João Leitão and Helena Alves. Cham: Springer.

Guerrero, Maribel, David Urbano, Alain Fayolle, Magnus Klofsten, and Sarfraz Mian. 2016. Entrepreneurial Universities: Emerging Models in the New Social and Economic Landscape. Small Business Economics 47: 551-63. [CrossRef]

Guerrero, Maribel, David Urbano, James A. Cunningham, and Eduardo Gajón. 2017. Determinants of Graduates' Start-Ups Creation across a Multi-Campus Entrepreneurial University: The Case of Monterrey Institute of Technology and Higher Education. Journal of Small Business Management. [CrossRef]

Harrison, John, and Ivan Turok. 2017. Universities, knowledge and Regional Development. Regional Studies 51: 977-81. [CrossRef]

Hisrich, Robert, and Michael Peters. 2002. Entrepreneurship, 5th ed. New York: McGraw Hill Irwin.

Hochschule Wismar. 2019. Degree Courses Taught in English. Wismar: University of Applied Sciences, Technology, Business and Design Wismar, Available online: www.hs-wismar.de/en (accessed on 14 September 2019).

Ierapetritis, Dimitrios G. 2016. Assessing Entrepreneurial Intentions of Secondary Education Students in Greece. Journal of Regional \& Socio-Economic Issues 6: 73-88.

Ierapetritis, Dimitrios G. 2017. Entrepreneurship Education at School: A Case Study on Secondary Education in Greece. World Review of Entrepreneurship Management and Sustainable Development 12: 271-89. [CrossRef]

Ierapetritis, Dimitrios G., and Dimitrios Lagos. 2012. Building rural entrepreneurship in Greece: Lessons from lifelong learning programmes. In Entrepreneurship, Social Capital and Governance: Directions for the Sustainable Development and Competitiveness of Regions. Heltenham: Edward Elgar Publishing, pp. 281-301.

Inzelt, Annamaria. 2004. The evolution of university-industry-government relationships during transition. Research Policy 33: 975-95. [CrossRef]

Isenberg, Daniel J. 2010. How to Start an Entrepreneurial Revolution. Harvard Business Review 88: 40-50.

Isenberg, Daniel J. 2011. Introducing the entrepreneurial ecosystem: Four defining characteristics. Forbes. May 5. Available online: https://www.forbes.com/sites/danisenberg/2011/05/25/introducing-the-entrepreneurshipecosystem-four-defining-characteristics/ (accessed on 14 May 2019).

Kakouris, Alexandros, Panagiotis Liargovas, and Cristina Sousa. 2018. Editorial. International Journal of Innovation and Regional Development 8: 281-85.

Kirby, David A. 2005. Creating entrepreneurial universities in the UK: Applying entrepreneurship theory in practice. Journal of Technology Transfer 31: 599-603. [CrossRef]

Kirzner, Israel. 1973. Competition and Entrepreneurship. Chicago: University of Chicago Press.

Kollmann, Tobia, Christop St $\varphi$ ckmann, Simon Hensellek, and Julia Kensbock. 2016. The 2nd European Startup Monitor. Berlin: ESM, Available online: https://europeanstartupmonitor.com/fileadmin/esm_2016/report/ ESM_2016.pdf (accessed on 14 April 2019).

León, Lorena Rivera, Kincső Izsak, Kastalie Bougas, and Victoria Soto. 2016. Regional Ecosystem Scoreboard, Methodology Report. Final Report. Bruxelles: European Cluster Observatory, European Commission.

MacLeod, Gordon. 1997. "Institutional thickness" and Industrial Governance in Lowland Scotland. Area 29: 299-311. [CrossRef]

Malecki, Edward J. 2018. Entrepreneurship and entrepreneurial ecosystems. Geography Compass 12: e12359. [CrossRef]

Maskell, Peter, and Gunnar Tornqvist. 2003. The Role of Universities in the Learning Region. In Economic Geography of Higher Education: Knowledge Infrastructure and Learning Regions. Edited by Frans Boekema and Roel Rutten. London: Routledge, pp. 129-44.

Mason, Colin, and Ross Brown. 2014. Entrepreneurial Ecosystems and Growth Oriented Entrepreneurship. Paper Presented at a Workshop of the OECD LEED Programme and the Dutch Ministry of Economic Affairs, The Hague, The Netherlands, November 7. 
Moore, James F. 1993. Predators and prey: A new ecology of competition. Harvard Business Review 71: 75-86. [PubMed]

Park, Han Woo. 2014. Transition from the triple Helix to N-Tuple Helices? An Interview with Elias Carayiannis and David F., J., Campbell. Scientometrics 99: 203-7. [CrossRef]

Poblete, Carlos, and José Ernesto Amorós. 2013. University Support in the Development of Regional Entrepreneurial Activity: An Exploratory Study from Chile. Investigaciones Regionales 26: 159-77.

Ronstadt. 1984. Entrepreneurship: Text, Cases \& Notes. Dover: Lord Pub., Business \& Economics.

Saxenian, AnnaLee. 1994. Regional Advantage-Culture and Competition in Silicon Valley and Route 128. Cambridge: Harvard University Press.

Schumpeter, Joseph A. 1934. The Theory of Economic Development. Cambridge: Harvard University Press.

Shaw, Julie Keane, and Janelle Allison. 1999. The Intersection of the Learning Region and Local and Regional Economic Development: Analysing the Role of Higher Education. Regional Studies 33: 869-902. [CrossRef]

Spigel, Ben. 2017. The relational organization of entrepreneurial ecosystems. Entrepreneurship Theory and Practice 41: 49-72. [CrossRef]

Spilling, Olav R. 1996. The entrepreneurial system: On entrepreneurship in the context of a mega-event. Journal of Business Research 36: 91-103. [CrossRef]

Stam, Erik. 2015. Entrepreneurial Ecosystems and Regional Policy: A Sympathetic Critique. European Planning Studies 23: 1759-69. [CrossRef]

Stam, Erik, and Ben Spigel. 2016. Entrepreneurial Ecosystems. Discussion Paper Series; Utrecht: Utrecht University, Tjalling C. Koopmans Research Institute, U.S.E., nr:16-13.

Sternberg, Rolf. 2012. Do EU regional policies favor regional entrepreneurship? Empirical evidence from Spain and Germany. European Planning Studies 20: 583-608. [CrossRef]

Trek Consulting. 2016. Research for the Evaluation of Employment and Career Structures Operated by Higher Education Institutes (Employment and Career Structures). 2nd Deliverable: Final Study-Evaluation Study, Special Managing Authority of the Operational Programme "Education and Lifelong Learning". Athens: TREK Consulting.

Walter, Sascha G., and Jörn H. Block. 2016. Outcomes of entrepreneurship education: An institutional perspective. Journal of Business Venturing 31: 216-33. [CrossRef]

World Economic Forum. 2014. Entrepreneurial Ecosystems around the Globe and Company Growth Dynamics. Davos: World Economic Forum, pp. 6-7.

(C) 2019 by the author. Licensee MDPI, Basel, Switzerland. This article is an open access article distributed under the terms and conditions of the Creative Commons Attribution (CC BY) license (http://creativecommons.org/licenses/by/4.0/). 